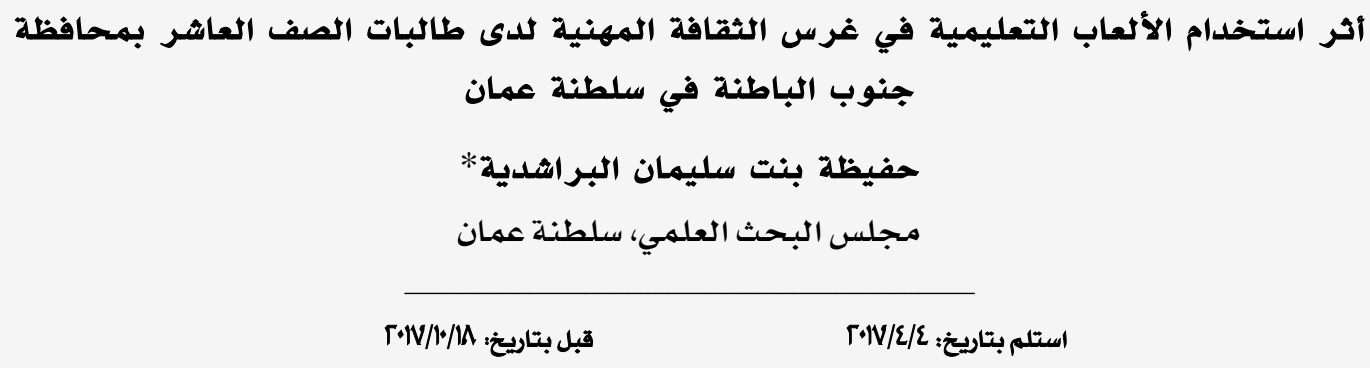

ملخص: هدفت هذه الدراسة إلى استقصاء أثر استخدام الألعاب التعليمية في اكتساب طالبات الصف العاشر للثقافة

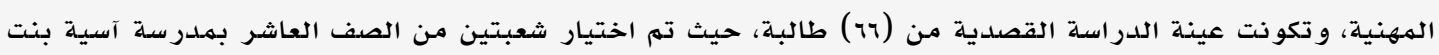

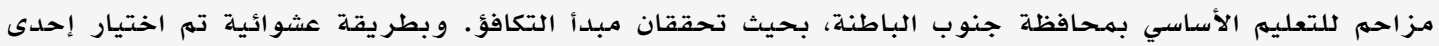

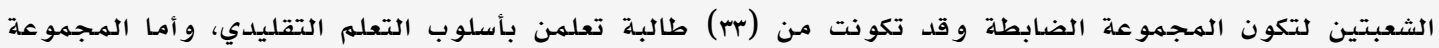

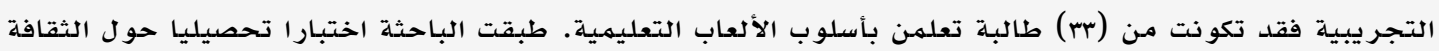

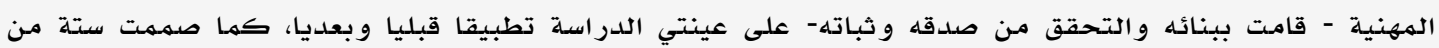

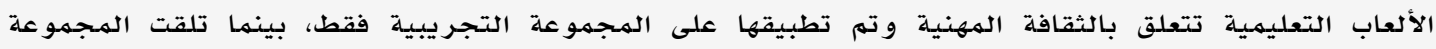

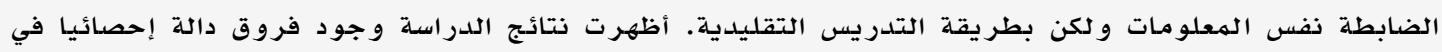
مستوى الثقافة المهنية لدى مجموعتي الدراسة و لصالح المجموعة التهن التجر يبية التي تعلمت بنمط الألعاب التعليمية. كلمات مفتاحية: الألعاب التعليمية، الثقافة المهنية، طلبة الصف العاشر، سلطنة عمان.

\title{
The Effect of Using Instructional Games in Teaching Career Culture to Tenth Grade Students at South Batina Governorate in Oman \\ Hafidha S. AlBarashdi* \\ The Research Council, Sultanate of Oman
}

\begin{abstract}
This study aimed to test the effect of using instructional games in teaching career culture to tenth grade students. The sample of this study consisted of 66 female students enrolled in Asia bint Mozahem Basic School, South Batina Governorate. This sample was devided into two groups: the experimental group $(\mathrm{N}=33)$, and the control group $(\mathrm{N}=33)$. The first group learned through normal instruction styles, while the other group learned through instructional games.The results revealed that there were statistically significant differences in the career culture achievement between the two groups in favor of the experimental group.
\end{abstract}

Keywords: Instructional games, career culture, tenth grade students, Oman.

*hafidhaalbarashdi@gmail.com 
سواء أكان طالبا يتحدد على أساسها عالمه و مشاريعه، أم طالبهة سوف تصبيح غدا عاملة أنة

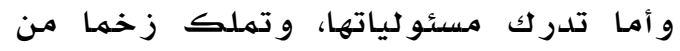

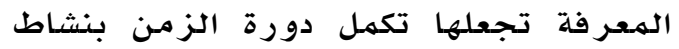
وحيوية من خلال تجربتها.

و تكمن الأهمية القصوى للألعاب في كونها تعلم الطالب مهارات الحياة الاجتماعية،

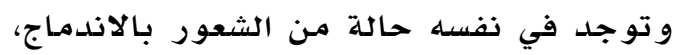

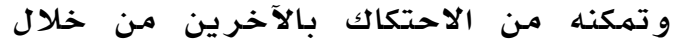

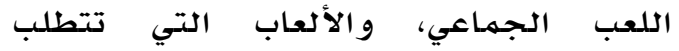

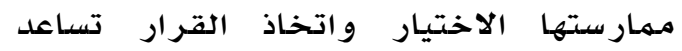
الطالب وتهكنه في المستقبل من التعامل

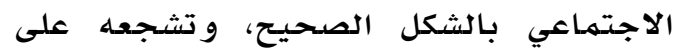
التعرف على العلاقات الاجتهماعية بأنواعها و طبيعتها سلبية كانت أم إيجابية.

ويعد اللعب سمة من سمات طلبـة مـرحلة

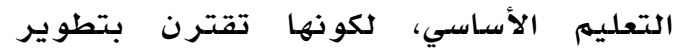
حياتهم فهي تساعد على نهوهم من ناحية، و لكونهم شديدي الميل بطبعهم إلى اللعب

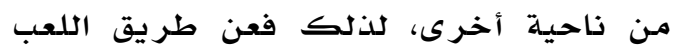
التعليهي يمكن بناء شخصية الطالب السوية

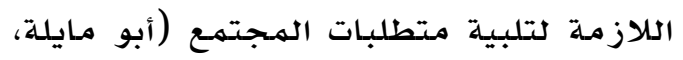
1991)، وحيث إن اللعب و سيلة الطالب ليتعله كل شيء عن نفسـه و عن العالم الهحيط بهله،

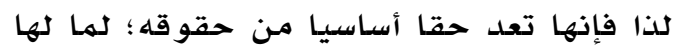
من تأثير بالغ في صحته النفسية والعقلية

و نال التعلم باللعب اهتماما كبيرا من قبل التر بويين و المتخصصين و المهتمين بالعملية

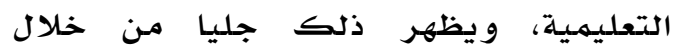
التوجهات التربوية الحديثة نحو استخدية التحام

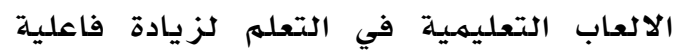

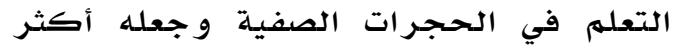
متعـة و إثارة. لذا ظهرت العديد من الدراسات التي قارنت بين طريقة الألعاب التعليمية والطريقة التقليدية في التدريس و منها دراسـة الجراج

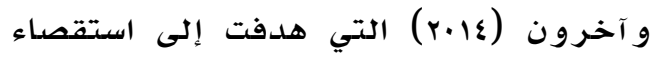

يعد إكساب الثّقافة الههنية للطلبة من أهــم الخدمات التي تسعى وزارة التربية و التعلـيـم العمانيـة مـثثلة في الهر كز الوطني للتوجيه

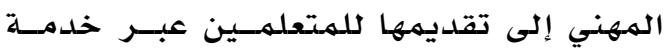
التوجيه الهـهني التــي اسـتحدثت فــي نظــام

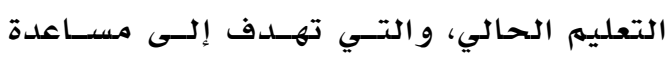

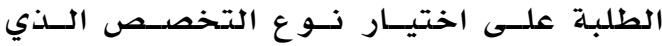

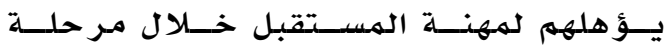

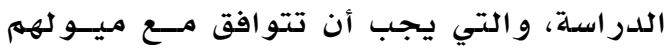
و اتجاهاتهم و استعداداتهم و قدر اتهم؛؛ وذذلــك لتحقيق أعلى درجة مــن التوافـق الشخصـي ولهـي و الاجتمـاعي، إلى جانب التوافق الههني.

و التربية الحديثة اليوم تؤكد على أهمية

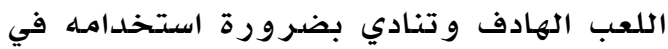
التعليه، لما لله من دور حيوي في تكوين أبعاد شخصية الطالب، كما أكد الإسلام

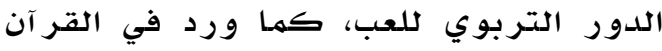

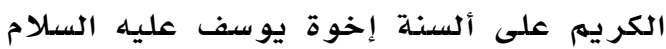

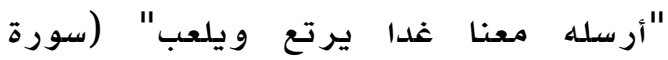
يوسف، الآية r 1)، و لقد كان رسئ رسول الله صلى

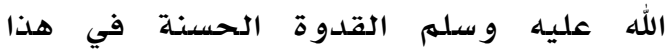
المجال فقد كان يلاعب أحفاده و أبناء الصحابة، ويروح عن نفوسهم، ويدخل

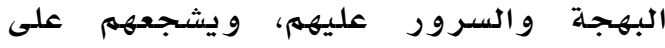

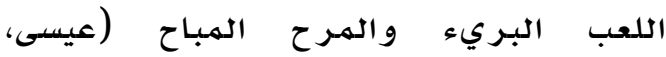

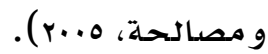

لذا نجد أن لكلألعاب التربوية أدوارا مهمهة في تشجيع الطلبة على الاتصال والتواصل والحوار والتفاهم مـع الآخرين، وخاصدة الطلبة الخجولين أو المنطوارين و والذين يحتاجون إلى تشجيع للتواصل مـع الآخرين (بلقيس و مـرعي، 191V) .

إن التعلهم باللعب يساهم في زيادة استيعاب الطالب وفتح مداركه و التتي على أسـاسها

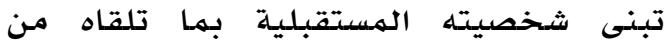

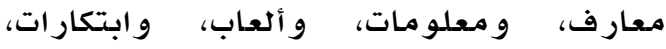

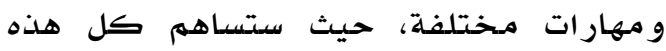
الأنشطة التعليميلة في دخوله عالم العمل؛ 
فـروق ذات دلادــة إحصــائية للتفاعـل بـين طريقة التدريس و النّوع.

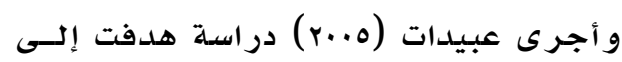

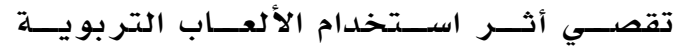

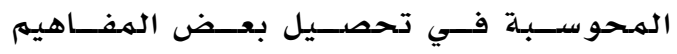

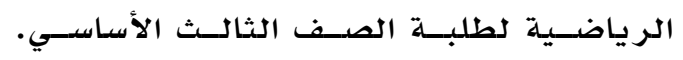

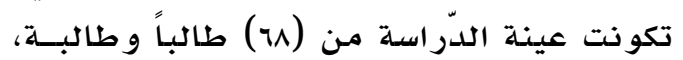

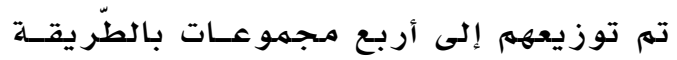

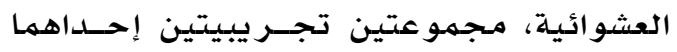

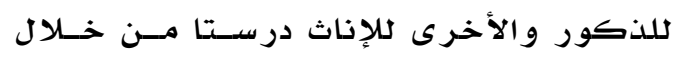

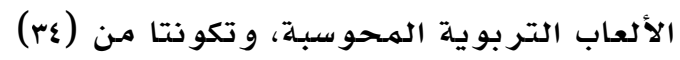

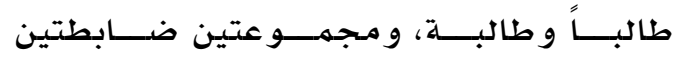

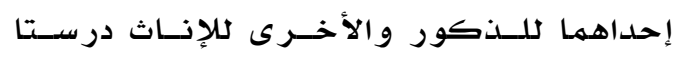
بالطّر يقة التّقليديلة و تكونتا مسنـ (عَ) طالبــاً

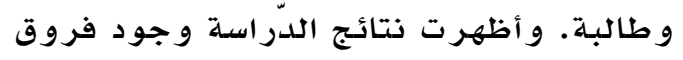

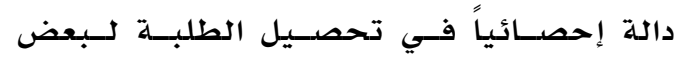
المفاهيم الرياضية علـى الاختبـار المباشـر

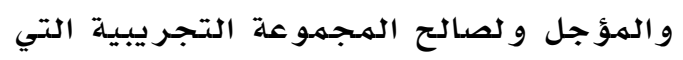

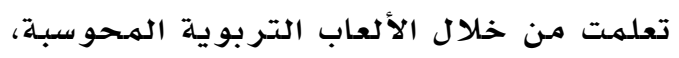

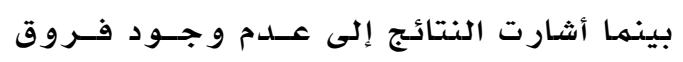

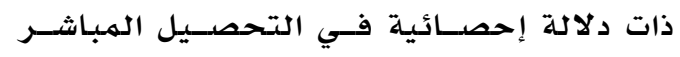

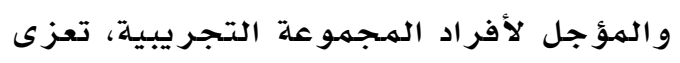
إلى النّوع. للمقار نة بين اســتخدام اسـتراتيجية الـتعلم

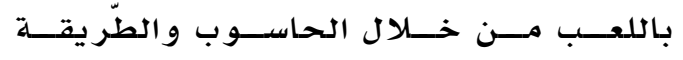

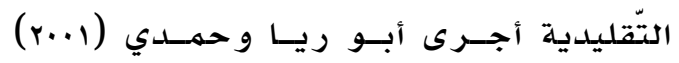

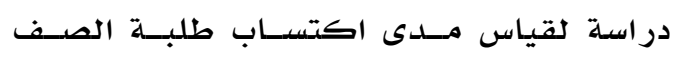

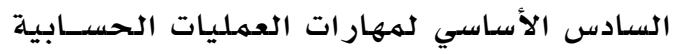
الأربعة، حيث تكونت عينة الدّراسـة من (1.1)

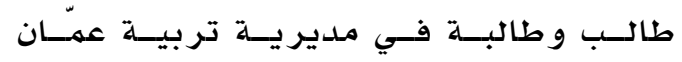

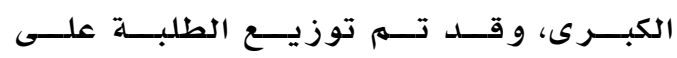

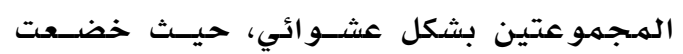

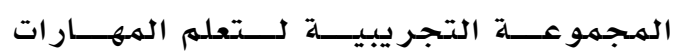

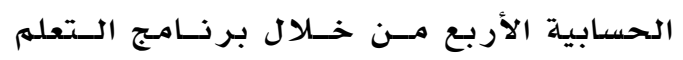
باللعب الهحوسب، أمـا الهجموعـة الضــابطة

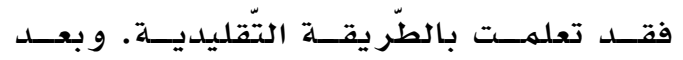
إخضاع المجموعتين لاختبـار يقيس التحصيل

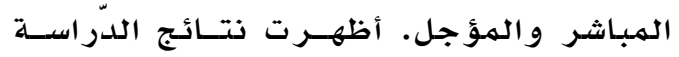

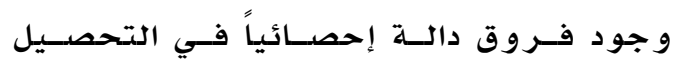

أثر التدريس باستخدام الحاسوب في تحسين مستوى دافعية المتعلمين نحو تعلهم

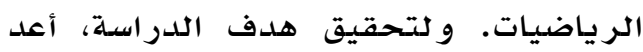

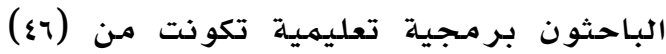
شريحة، تضمنت تدريبات وا أنشطة يتهم

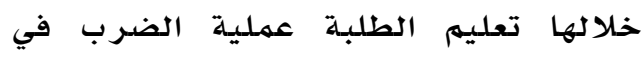

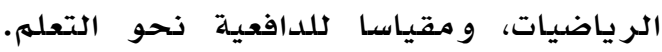

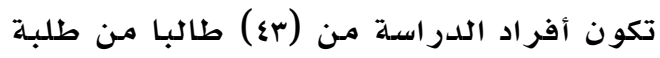

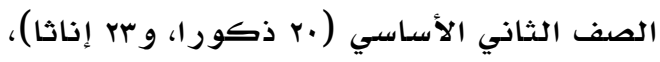
وزع أفر اد الدراسـة عشوائيا في مجهموعتين في المهجموعة التجريبية درسوا باستخدام

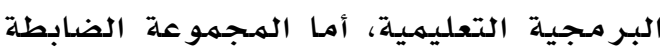

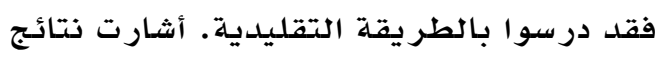
الدراسة إلى وجود فروق ذات دلالة إحصدائية

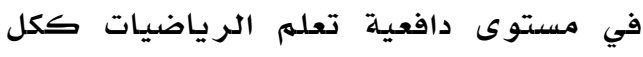

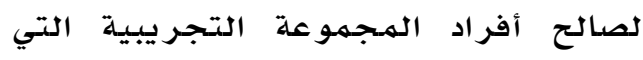

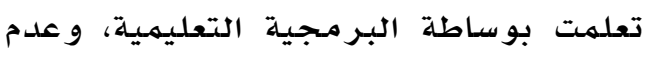

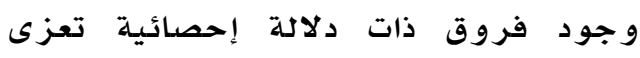
للجنس أو للتفاعل بين الجنس وطودريقة التدريس، ووجود فروق ذات دلانة إحصائية

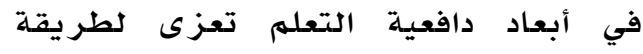
التدريس لصالح أفر اد الهـجموعة التجريه يبيـة. أمـا در اسـة (زيدان، و عفانة، V...

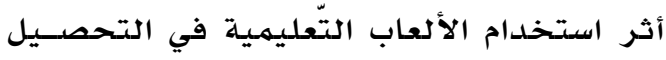

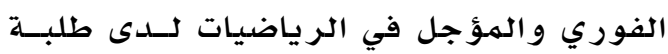

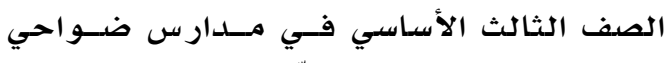

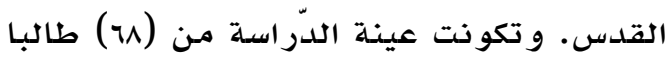
وطالبـة تم اختيـارهم بطريقـة قصسدية مسن

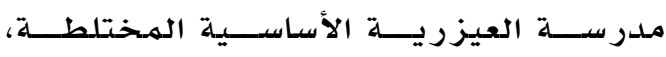

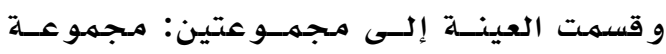

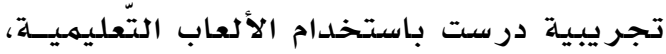

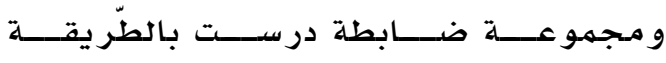

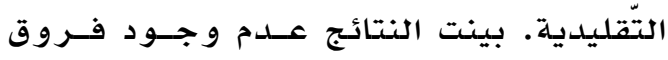
ذات دلالدة إحصــائية فـي التحصـيل الفــوري

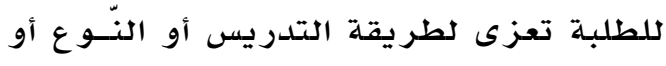

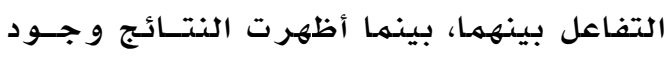

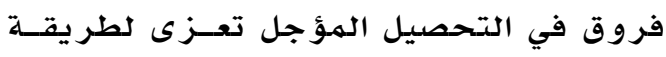

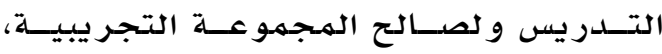
ومتغير النّـوع لصــالح الإنـاث، و لـهم تظهـر 
و هنــاك دراســة كـابلن (Kablan, 2010)

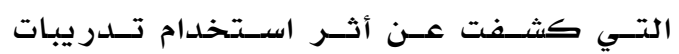
رياضية محوسبة بطريقة الألعاب التعليميـة

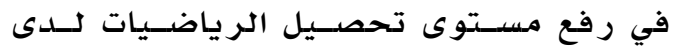

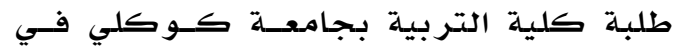
تركيـا. تكونست عينــة الدر اســة مــن (Irv)

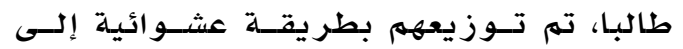

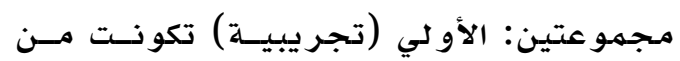

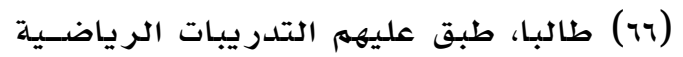
مصهمهة بطريقة الألعساب الالكترو نيسـة لهـدة

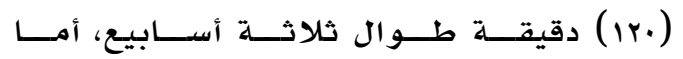

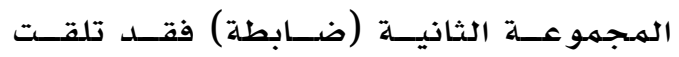

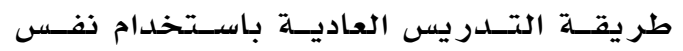

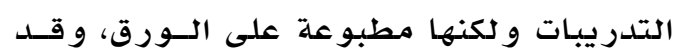

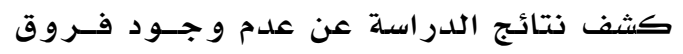
دالة إحصائيا بين الهـجموعتين فسي مسـتوى

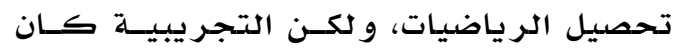

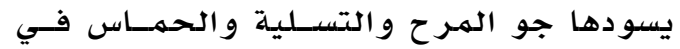
التعلهم مقار نة بالمجهمو عة الضابطة. للكشـف عـن أثـر لعسب الأدوار فـي تنـميسة

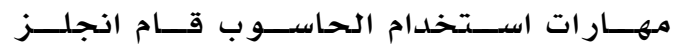
وجير لين (Engels \& Geralien, 1994) بدر اسلة

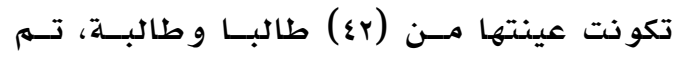
توزيعهم بطريقة عشوائية إلى مجهـو عتين:

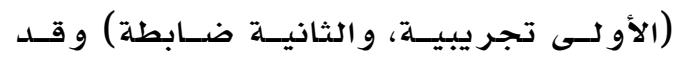

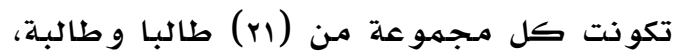

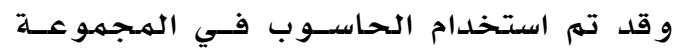

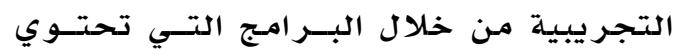

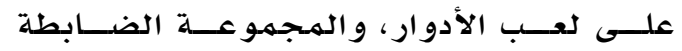

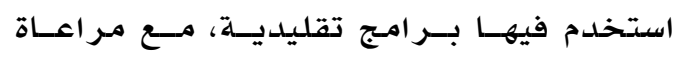

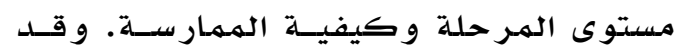

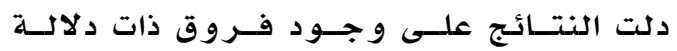
إحصائيـة لصالح المجمهو عة التجر يبيسة التـي

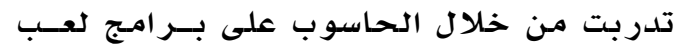

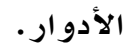

لذا يعد التدريس باستخدام الألعاب التّعليمية

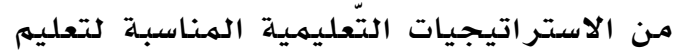

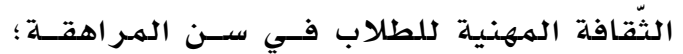

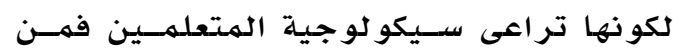

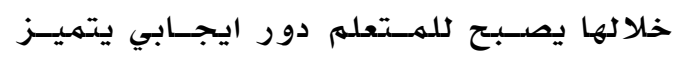

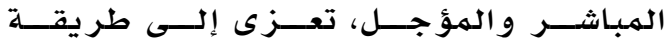

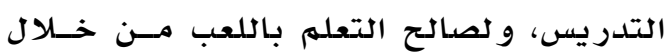

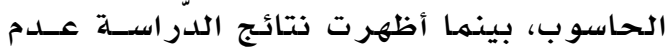

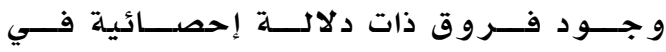

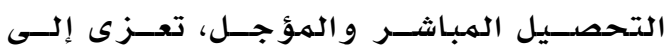

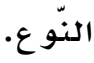

و للتعرف على أثر استخدام الألعاب

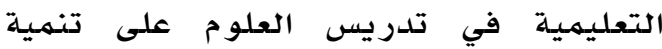

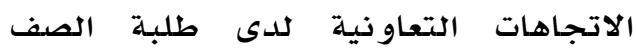

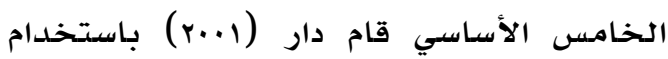

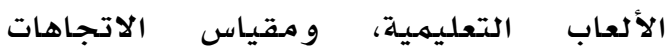

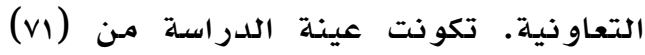
طالبا وطالبة، تم توزيعهم على مجموعتين

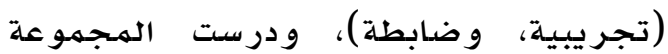
التجريبية الوحدتين المختارتين باستخدام

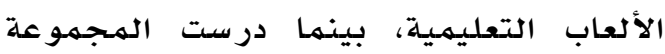

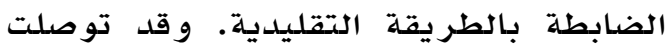
نتائج الدراسـة إلى و جود فروق دالهيلة إحصائيا

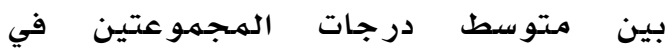
التطبيق البعدي، ولصئح التجر يبية.

و في دراسـة (الهرش، و عبابنة، و الدلالعسة،

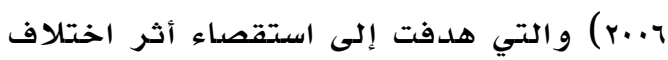

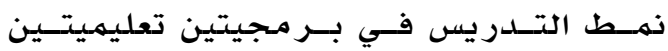

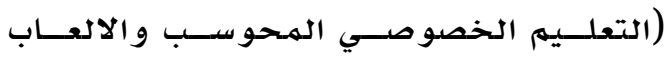

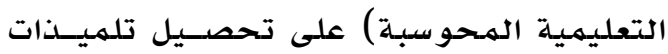
الصف الأول الأسساسي فـي مسادة الرياضــيـات.

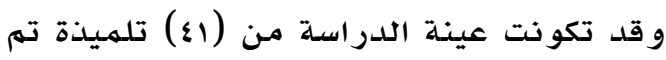
اختيار هن بطريقة قصدية، وتم تقسيم أفر اد العينـة إلـى مسجمـو عتين بطريقـة عشـوائية:

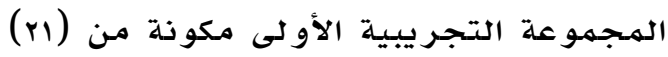

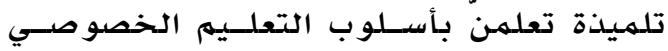

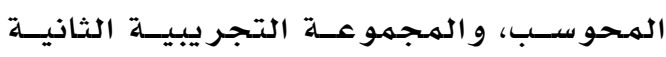

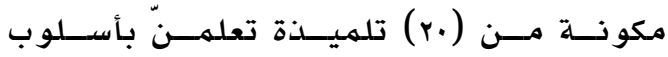

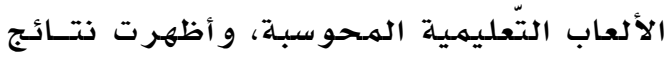

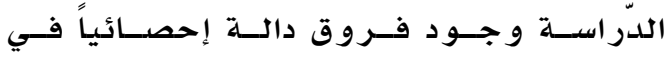

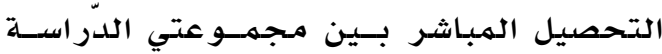

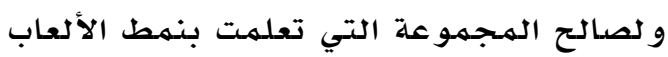

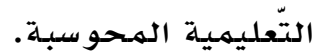


لهم تتحسن قدرات الهجمو عة الضابطة إلا في

$$
\text { تر كيب المكعبات و النسبخ) }
$$

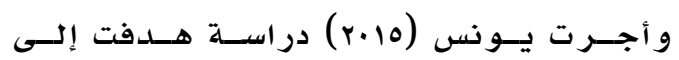

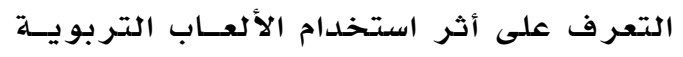

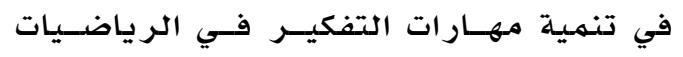

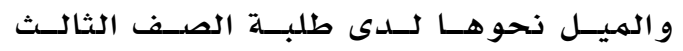
الأساسي. تكونت عينة الدراسـة مـن (.7) طالبـا تم توزيعهم عشوائيا إلى مجمو عتين (ضابطة الابنة

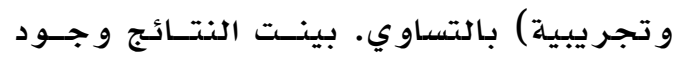

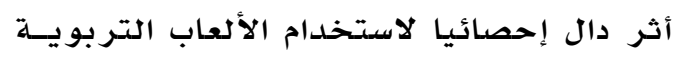

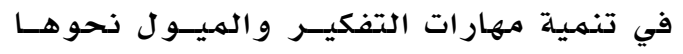
لصالحة المـجموعة التجري يبية.

و لاستقصاء أثر استخدام الألعـاب التعليميـة

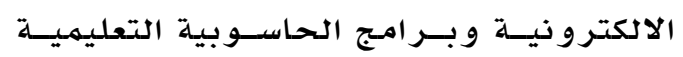

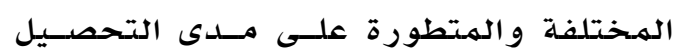

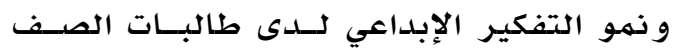

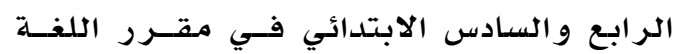

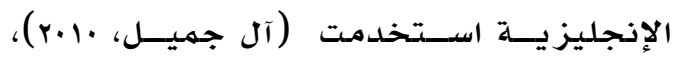

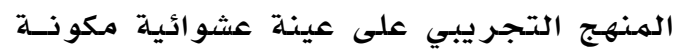

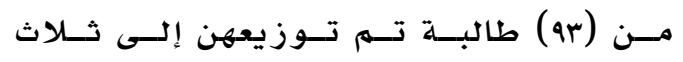

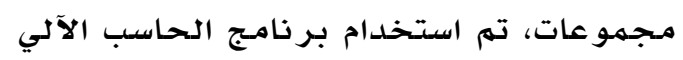

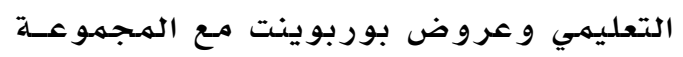

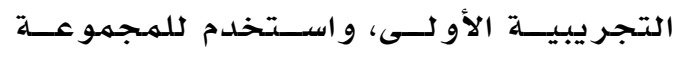

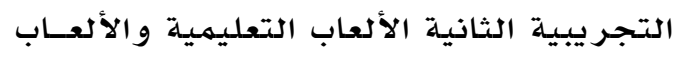

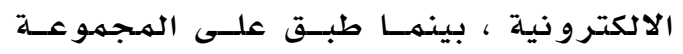

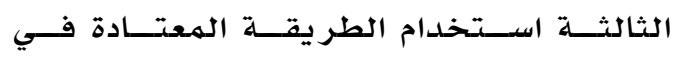
التدريس كهمبمو عة ضابطة، ولقيـاس أثـر

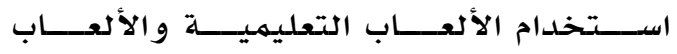

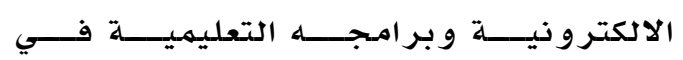
التحصــيل. اســتخدمت الدراســــة اختبـــارا

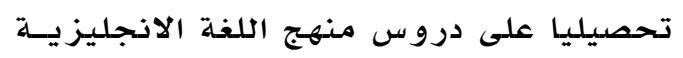

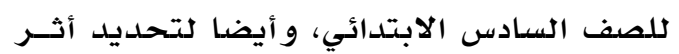

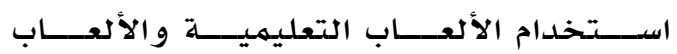

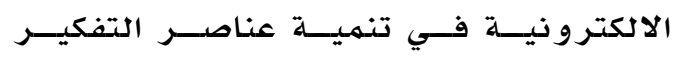

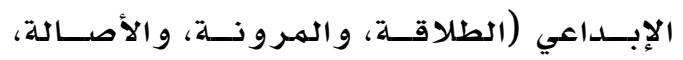

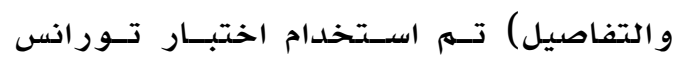

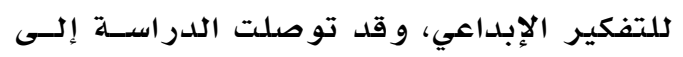

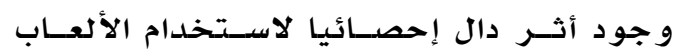

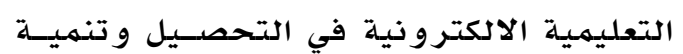

بكو نه عنصر ا نشطا و فعالا داخل الصف، و لما يتسهم بـه هذا الأسلووب في التعليهم من التفاعل

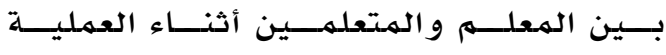

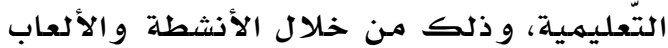

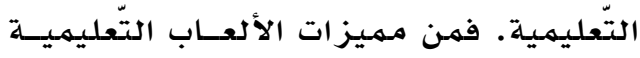

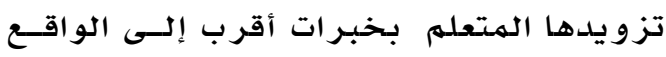
العملي، وتساعد على زيادة إيجابية المتعلمين

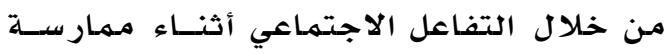

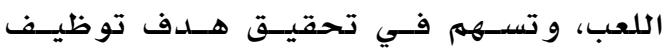
الهعلومـات مثل القدرة على تطبيق الحقــائق

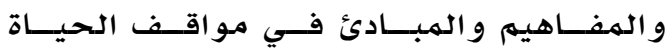
المختلفة، ووفي تنفيذ ألعاب تعليمية يســودها

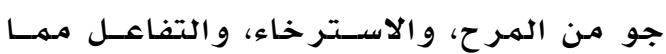

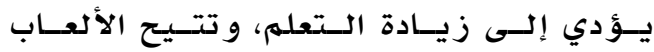

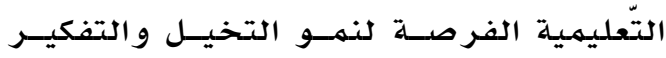

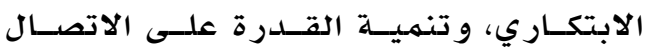

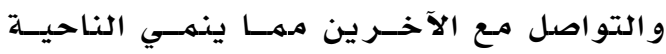

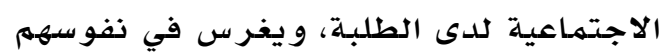

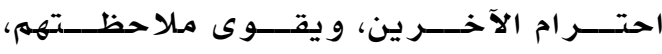

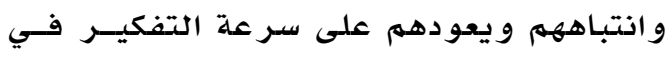

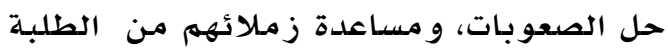
الضعحاف، و يحو لهم إلى مشــار كين ايجــابيين و فاعلين أثناء اللعب.

لذا قامت العديد مـن الدراسـات بقياس أكثـر

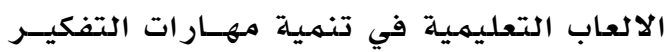

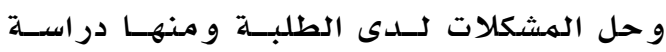

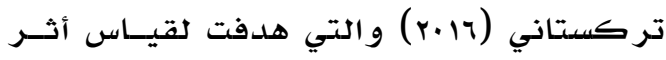

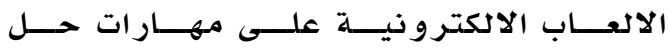

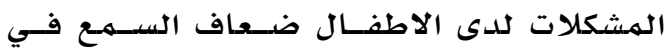
الرياض. تكونت عينة الدراسـة (17) طفلا تم

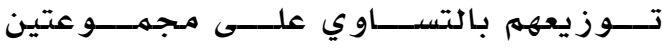

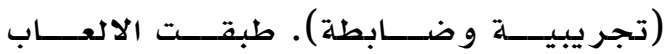

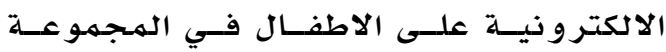

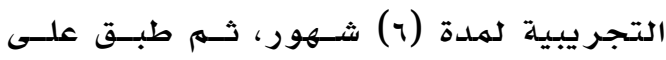

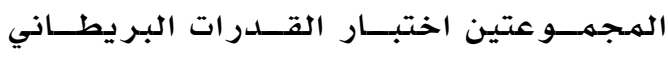

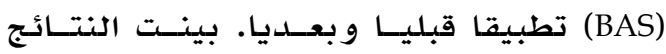

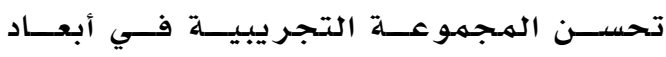

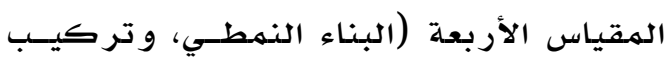

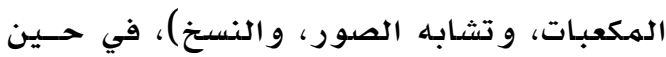


باختيار المــواد الدراسـية التسي يرغسب فـي

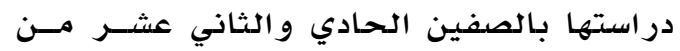

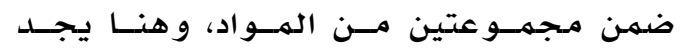
الطالب نفسـه أمام نقطة تحول تتطلـب منــه

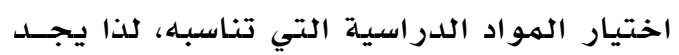

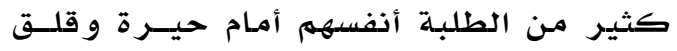

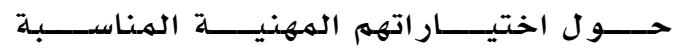

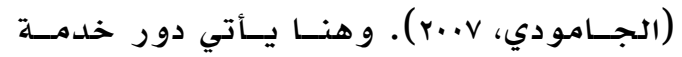
التوجيه الههني المقدمسـة بالهــدارس وس والتـي تعمل على توعية هؤلاء الطلبـة نحــو اختيـار

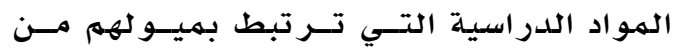

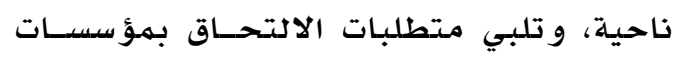

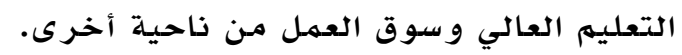
إذ لا بـ للطلبــة مــن امـتالاك ثقافــة مهنيــة

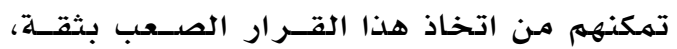

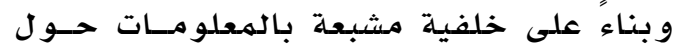
نتائج هذا القرار المستقبلية، وهن من هنا تـأتي

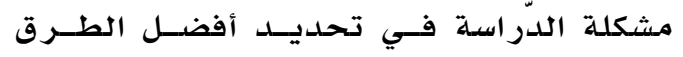

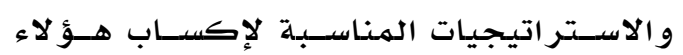
الطلبة في هذه السن للمعلومهـات و المفــاهيم التي تقوي من ثقافتهم المهنيـة.

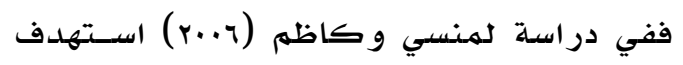

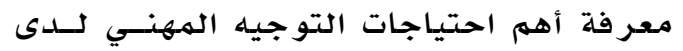

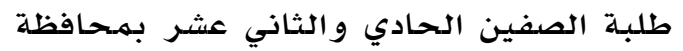

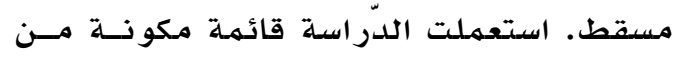

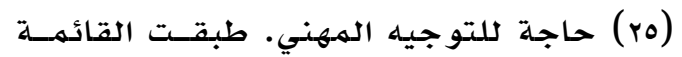

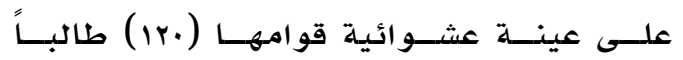

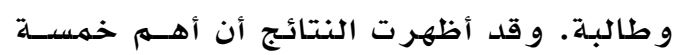

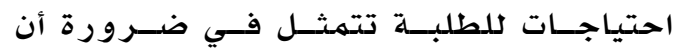
يعرف الطالب: قدراتـه العقليـة، والمهــارات

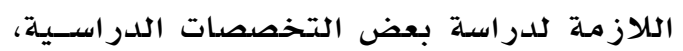

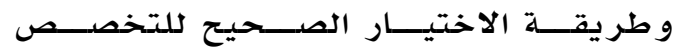

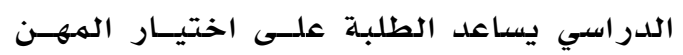

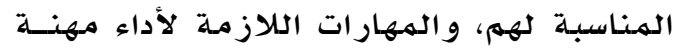

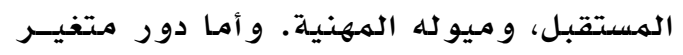

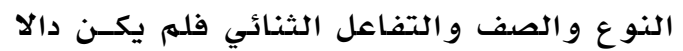

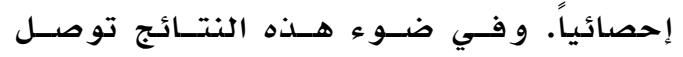

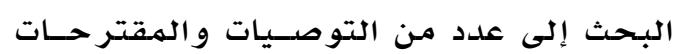

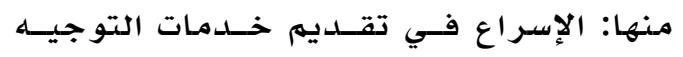

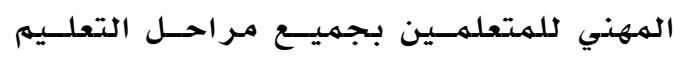

عناصر الإبداع لصالح المجموعة التجريبيـة الثانية .

وأجرى عيسى ومصالحة (r...0) دراسـة

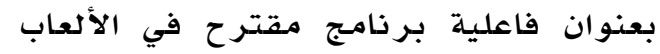

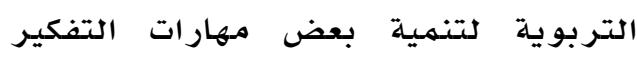

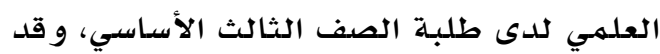
تكونت عينة الدراسة من (جه) طالبـا و طالبة، استخدمت الدراسة بر نامـج مقترح و اختبـار في مهارات التفكير، وقد توصلت نتائج

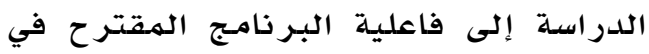

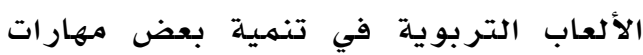
التفكير العلمي للىى طلبة الصف الثالث الأسساسي، بينما له توجد فروق دالة إحصائيا

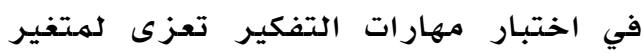
التحصيل الدر اسي.

ولتطوير نموذج للعبـة كمبيوتريـة مرنة وقابلة للتكييف لتسهيل تعله الرياضيات عبر

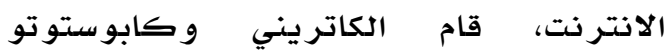

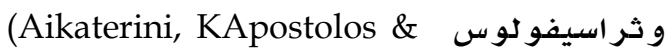
Thrasyvoulos, 2014) تدريس الرياضيات، لكونها من المواد المعقدة بالنسبة للطلاب من جميع الأعمـار. و ويمكن

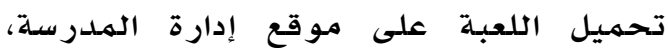

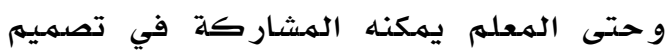

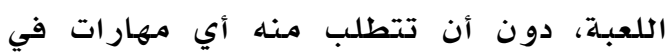

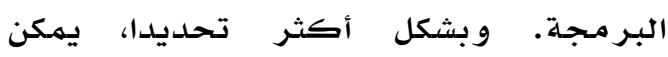
للمعلم استخدام موقع الإدارة من أجل تغيير

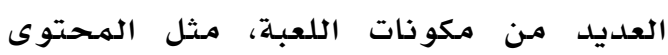

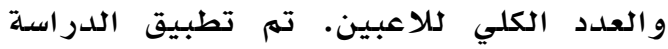
التجر يبية على عينة مكونة من العدل (r) طالبا،

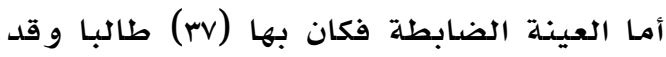

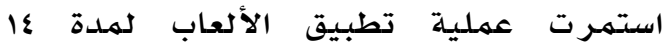
أسبوعا. أشارت النتائج إلى أن رأي الطلاب تهبئ حول اللعبـة كان إيجابيا، كها تشير النتائج إلى فعالية اللعبـة كأداة تعليمية في تعليهم الر ياضيات. مشكلة الدراسة يعتمد نظام التعليهم في سلطنة عمان على أن يقوم الطالـب فـي الصـف العاشـر الأساسـي 
الدر اسية، فضلا عن تزو يدهم بـبعض نمـاذج

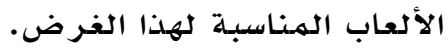

\section{أهداف الدراسة}

هدفت الدّر اســة إلـى قيـاس أثـر اسـتخدام

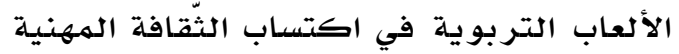

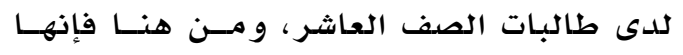
حاولت الإجابة عن السؤال التالي:

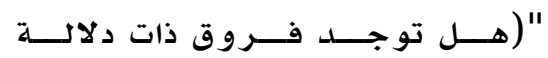

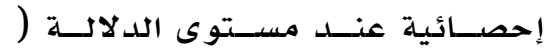

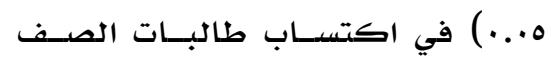

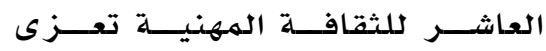

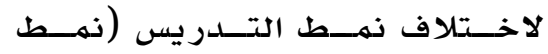
التدريس التقليدي، ونمط التدريس

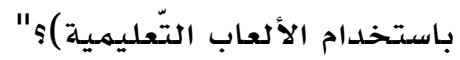

فرضية الدراسة

حاولت الدّراســة الحاليسة فـي ضــوء نتـائج

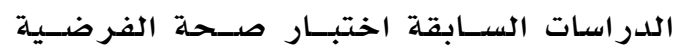

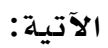

"توجـــ فـروق ذات دلالـــة إحصــائية عنــد مستوى الدلالد ( ه...) في اكتسـاب طالبـات

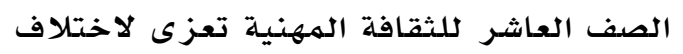

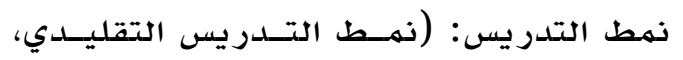

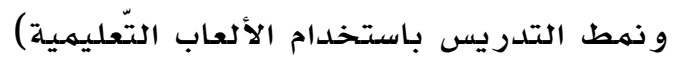

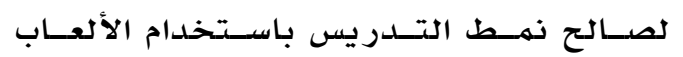

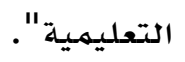

أهمية الدراسة

تكمن أهمية الدّراسـة الحالية في الآتي:

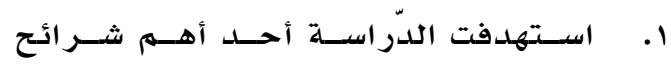

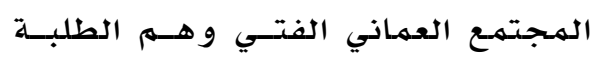

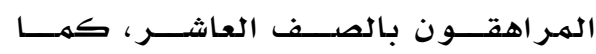

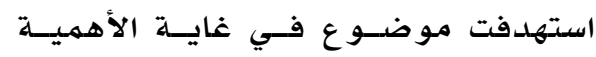

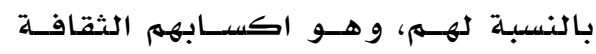

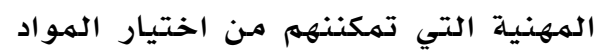

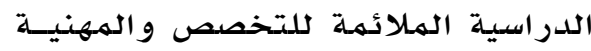
المستقبلية التي يتطلعون لها.

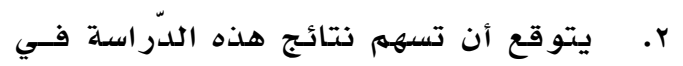

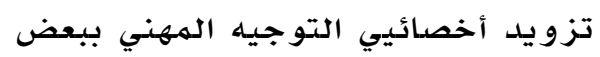

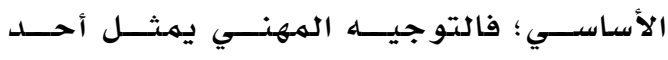

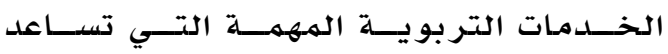

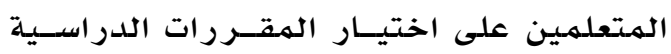

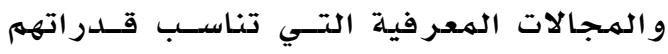
و ميو لهمر و استعداداتهم.

مـما يؤكس حاجـة الطلبـة لاكتســاب الثّقافـة

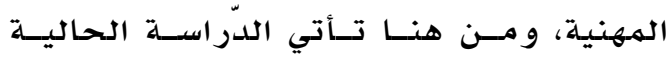

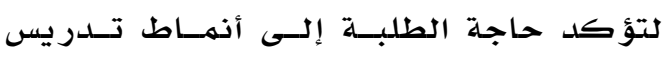

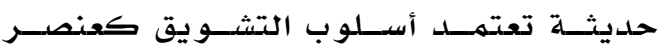
أساسي فيها بهدف إكساب الطلبة في مرحلة إسلة

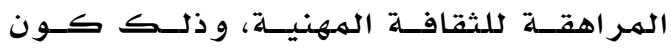

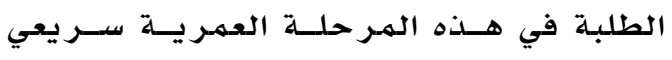
الانشغال داخل الغرفة الصفية بأبسط الأمور .

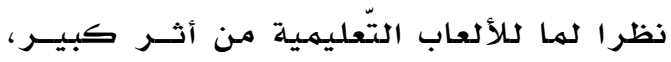

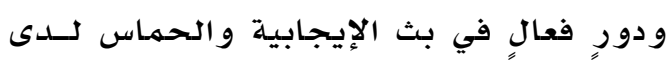

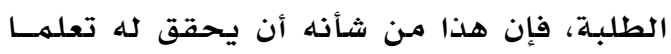
أكثر استمـر ارا و فائدة، بجانب ما قـد يهيئسـه

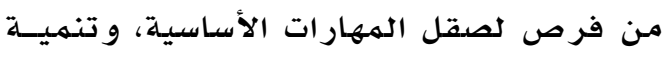

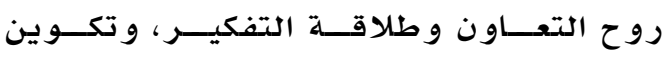

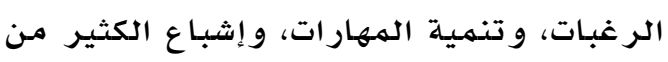
متطلبــات الجـانــب الوجــــاني مثــل الشــعور

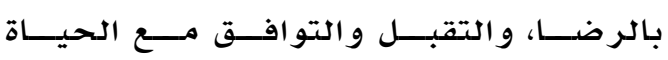

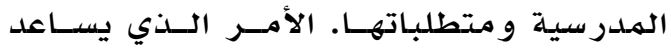

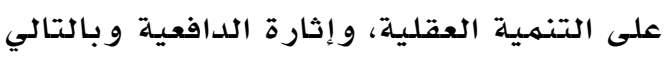

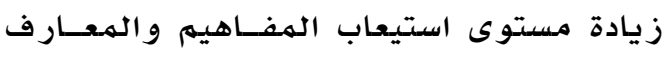
الههنية. لذا تحاول هذه الدرّاســة أن تقـارن

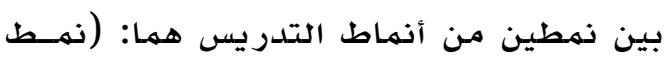

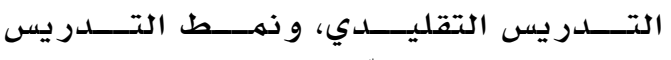
باستخدام الألعاب التّعليميلة). وحيث لا يوجسد -علــى حسـ علـهم الباحثـة دراسات سابقة عن استخدام الالعاب التعليمية

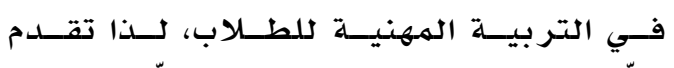

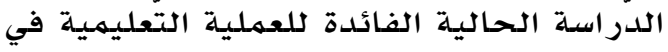
مـجال التوجيه الههني من حيث إنهـا تســاعد التها

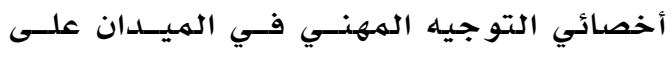

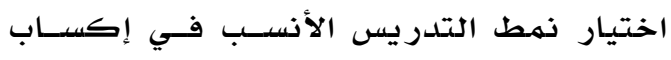

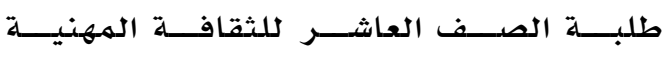

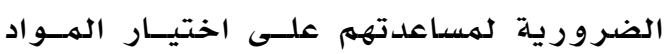


إحصائيات وزارة التربية و التعليم (محافظــة

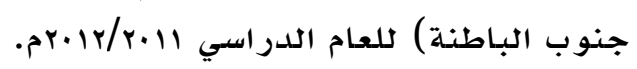

عينة اللّراسـة

تكون أفر اد عينـة الدّراسلة مـن شـعبتين مــن

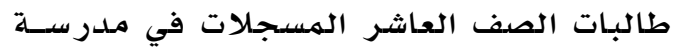

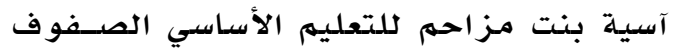

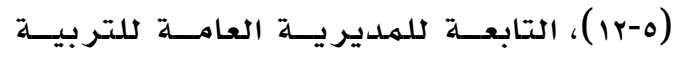

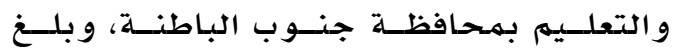

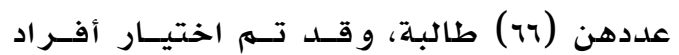

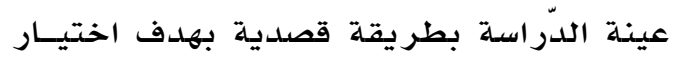
شعبتين متكافئتين في المستتوى التحصـيلي. و تم اختيار إحدى الشعبتين بطريقة عشوائية

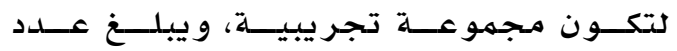
الطالبات بها (rr) طالبة تعلهنّ بنمط الألعاب

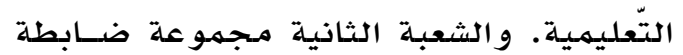

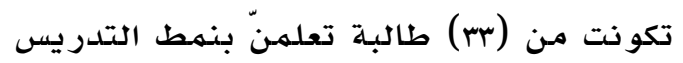
التقليدي.

و لأغــر اض التحقــق مــن تكـافؤ مـجمــوعتي

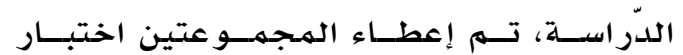

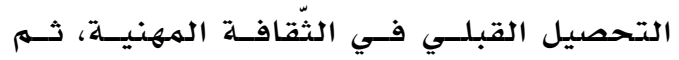

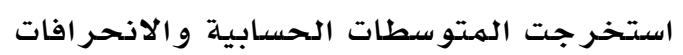

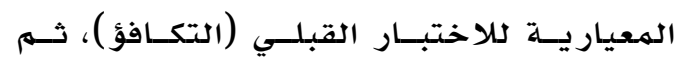

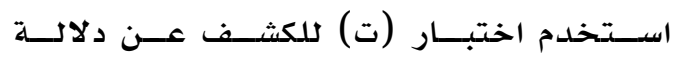

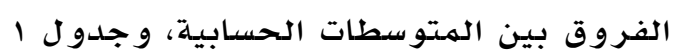
يبين نتائج الاختبـار القبلي.

يتضع من جدول ا عدم وجود فـروق داتـة

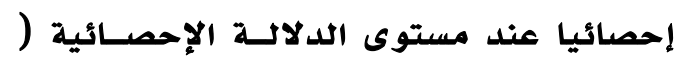

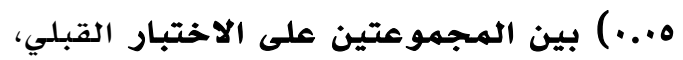

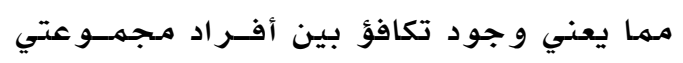

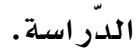

الاستر اتيجيات والألعاب التي يمكـن أن

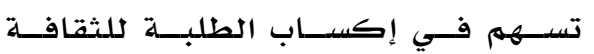
المهنية.

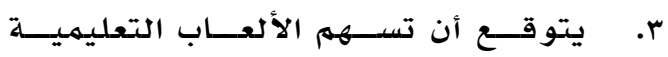

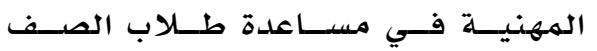
العاشر على اتخـاذ القرار الههني بشــأن اختيار المواد الدراسية للصفين الحمادي

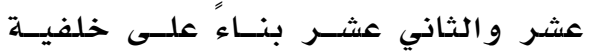

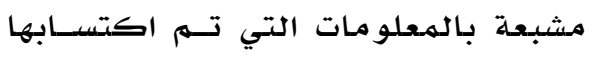
بطر يقة ممتعة و مشوقة.

ع. تسـلط الدراســة الضــوء علــى أهميــة

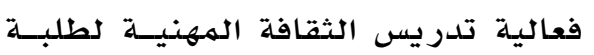

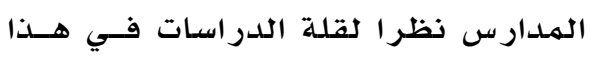

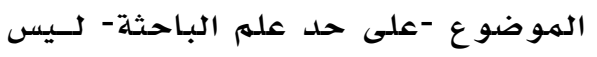
في السلطنة فحسب وإنهـا فـي الـوطن العربي أيضدا.

الطريقة والإجر اءات

منهج الدراسة

للتحقـق مــن صـحة فرضـيات الدراسـة

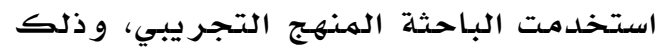

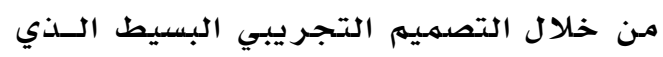
يتهم فيه القياس القبلي والبعدي للمجرموعتين التجر يبية و الضابطة. مجتمع الدّراسة يتكون مـجتهـع الدّراسة الحساليـة مـن جميــع

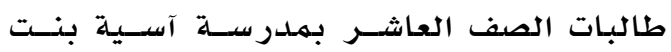

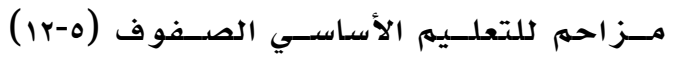
بمسحافظة جنوب الباطنة، ويبلـغ عدد طالبـات

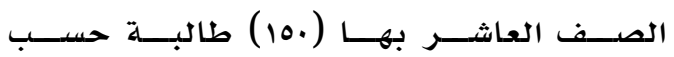

جدول

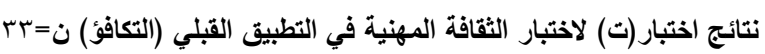

\begin{tabular}{ccrrrr}
\hline المجموعة التجريبية \\
\hline
\end{tabular}


حيث بر امجها و تخصصاتها واحتياجات سوق

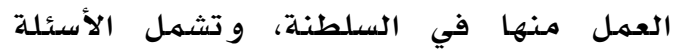

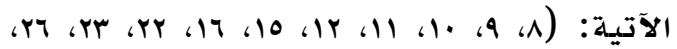

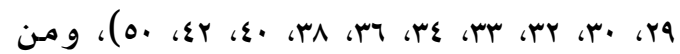

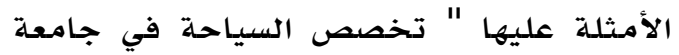

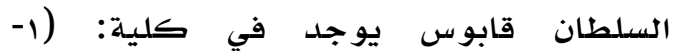
السياحة، ب- الآداب و العلوم الاجتمهاعية، بـ

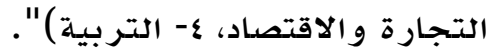

صدق أدوات الدّرّاسة وثباتها صدق الألعاب التّعليمية: بعد تصميم الألعاب

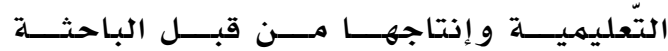
و بمساعدة أخصـائيات التوجيـهـ الههنـي فـي

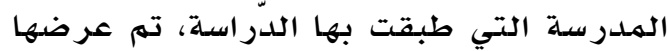
على مجسمو عة مــن المهحكمـين المتتخصصـين

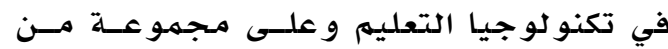
أخصدائيي التوجيه المهني في وزارة التربيسة

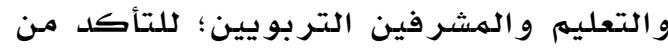

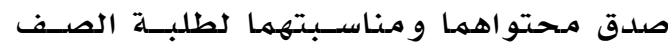

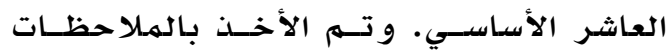

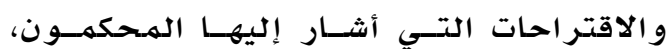

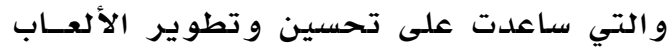

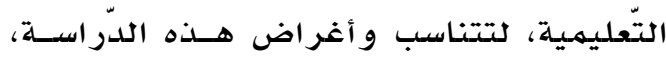

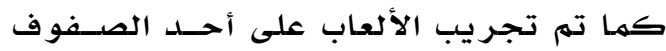

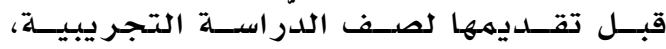
و الأخذ بمالاحظات الطلبة بشأذها. صدق اختبار الثّقافــة المهنيـة: تـهم عـرض

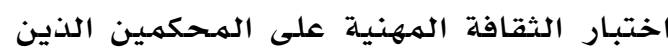

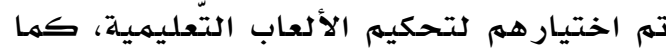

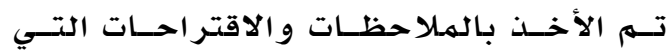

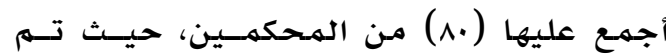

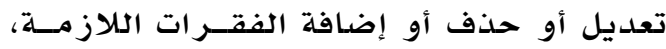

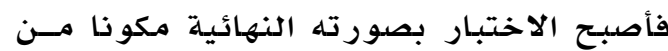

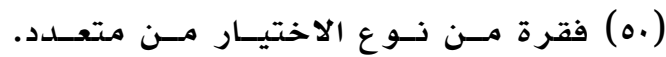

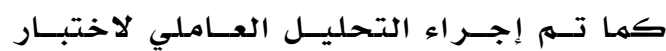
الثقافة المهنيـة للتعرف على البنية العامليـة

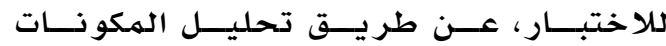
الأسـاسـية لهـوتلنج ( Principal Component

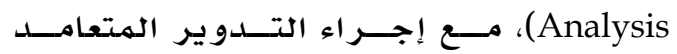

أدوات اللّرّاسة

الألعاب التّعليمية: قامت الباحثة بتصميهم ستة ألعــاب تعليميـــة تحتــــوي علـــى مفـــاهيم و معلومات عن الثقافة المهنيـة وهـي: لعبــة تعرف على مؤسسـات التعليهم العـالي، و لعبــة

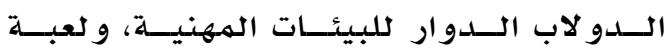
الوصول للكأس، و لعبـة الكلهـات المتقاطعـة، و لعبة السلم و الأفعى، و لعبـة سؤال و جواب.

اختبار الثقافة المهنية: لتحقيق أهداف الدراسلة قامت الباحثة ببناء اختبار تحصيلي

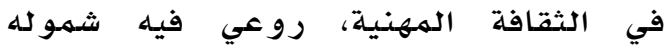

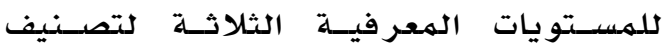
بلوم الهعرفي (التذكر و الفهم والتطبيق).

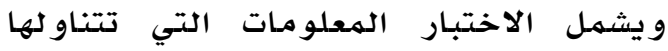

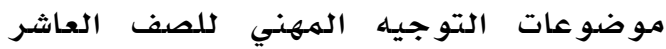
والتي بنيت عليها الألعاب التعليهية، وهو

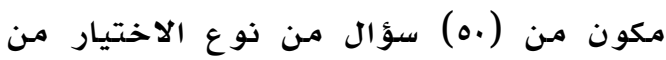
متعدد، وقد حددت لكل مفردة، أربعة بـدائل. و قد تكون الاختبار من ثلاثة أبعاد كالآتي:

الميول و المهارات المهنية: ويتضمن هذا

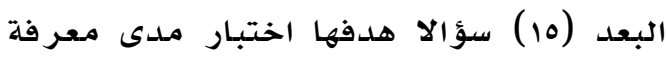
الطالب بالميول و الههارات المهنية، و وتشهل

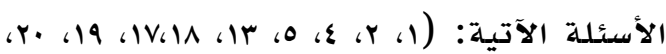

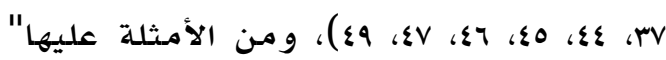
إذا كانت ميولاتي المهنية تتجه للطب فإن

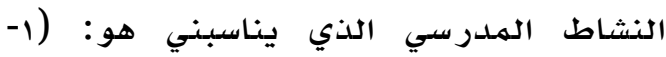

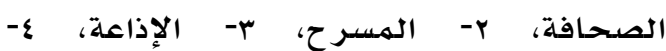
الصححة)".

المهن: يتضمن هذا البعد (10) سؤالا هدفها

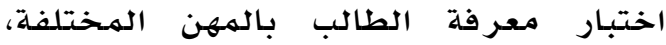

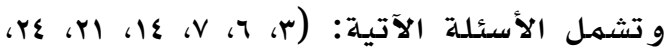
(YO

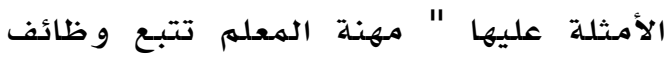

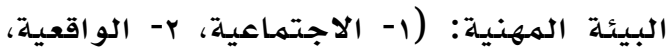

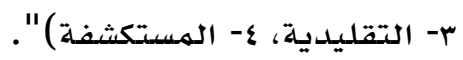

مؤسسات التعليم العالي وسوق العمل: و يتضمن هذا البعد (.r) سؤالا هدوفها وليعا اختبار

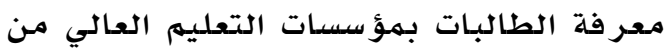




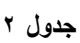

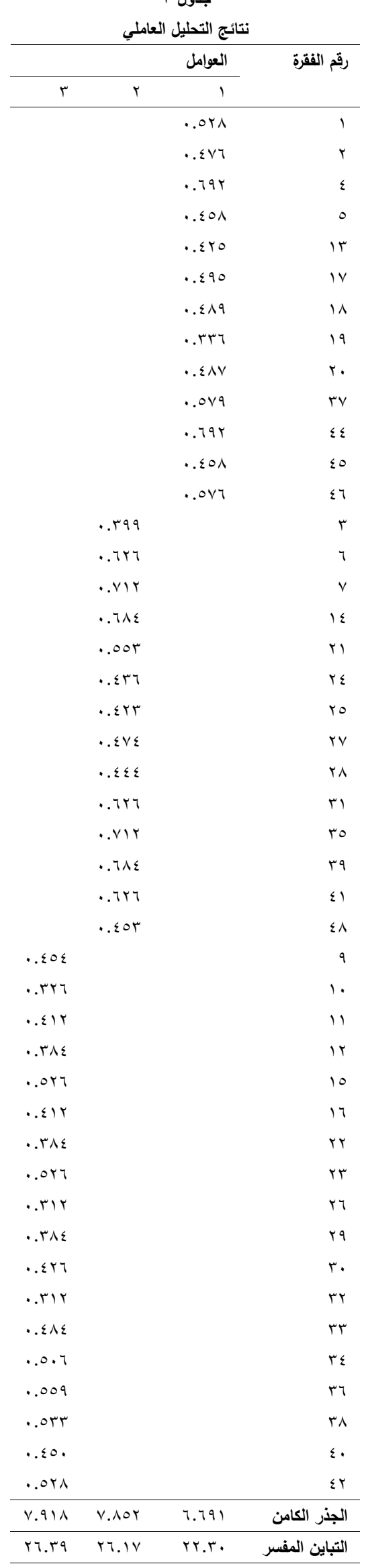

بطريقة الفاريهـاكس (Varimax Rotation)،

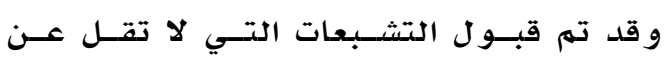

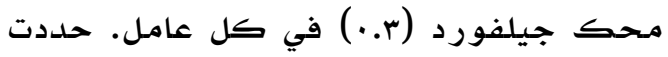

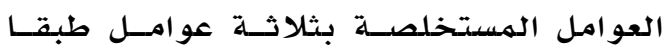

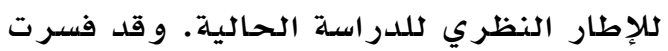

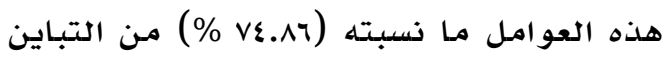

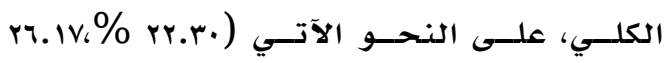

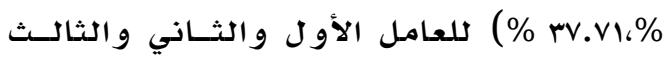

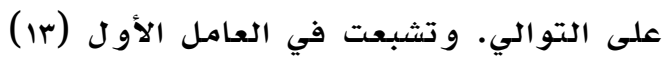

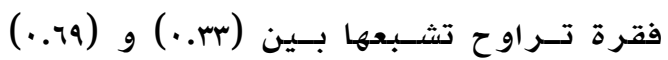

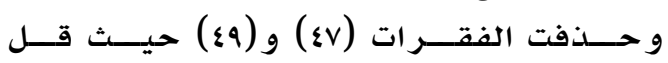
تشبعهما عن (r..)، و تشبعت الفت في العامل الثاني

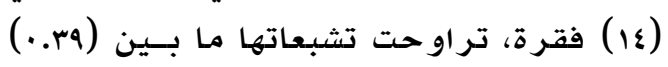

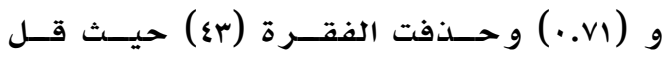

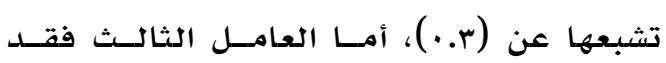

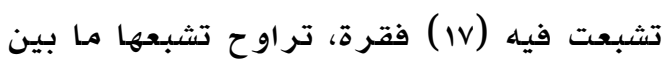

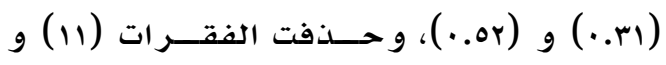

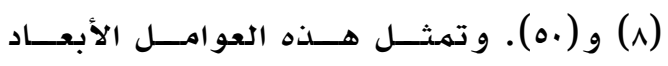

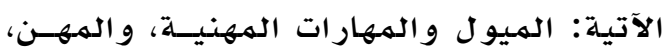

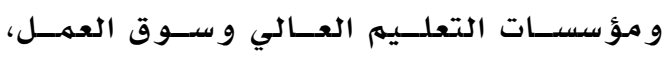

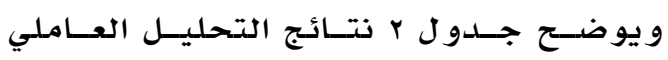
كلاستبـانة.

و للتأكد من ثبات اختبار الثقافة المهنية،

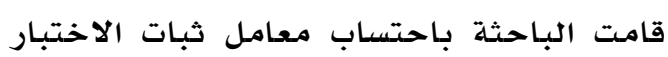

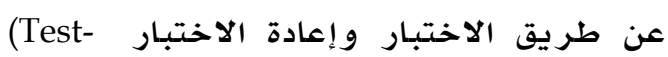

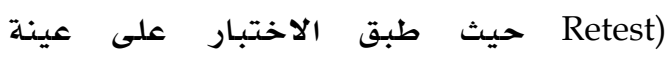

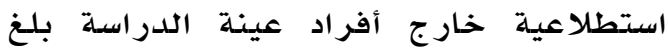
عددها (ro) طالبة. و كان ذلكارجة ألك على فترتين زمنيتين يفصل بينهما أسبوعان، حيث إنهان حسب معامل ارتباط بيرسون و بلـغ معامل

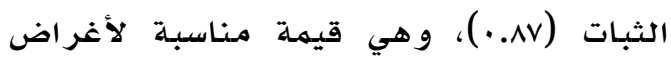
تطبيق هذه الدراسـة.

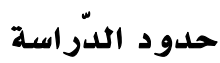
الحدود البشرية: اقتصر تطبيق الدراسة على

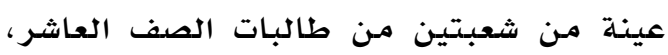
بلغ عددهن (7т) طالبـة. 
الثقافة المهنية: إجرائيا بأنها

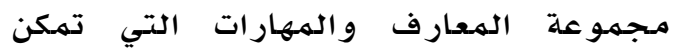

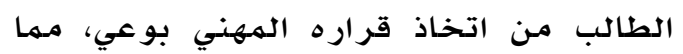

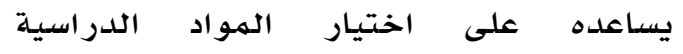

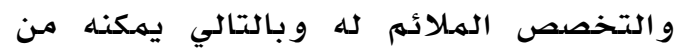
التكيف بفعالية في عالم العمل مستقبلا، و تحدد بمقدار الدرجة التي يحصل عليها

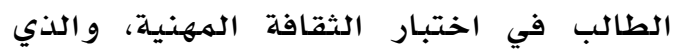

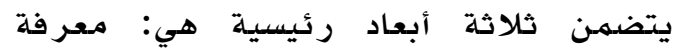
الهيو ل و المهارات الههنية، والهعر فهة بالههن،

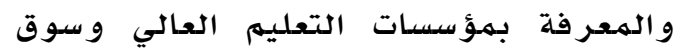
العمل.

\section{إجر اءات الدراسة}

لتحقيق هدف الدراسدة، تم اتباع الخطوات الآتيـة:

$$
\text { ا. تصميهم الألعاب التعليمية. }
$$

r ب بناء فقرات اختبار الثقافة الههنية. r. التحقق من صدق وثبات أدوات الدراسلة مـن خلال التطبيق على عينة

$$
\text { استطلا عية. }
$$

ع.اختيار أفراد عينة الدراسـة الفعلية (الهجمهو عتان الضابطة و والتجريبية)

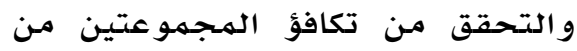
أجل ضبط العوامل المؤثرة على مسار

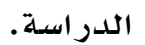

تدريب أخصائيات التوجيه الهـهني في

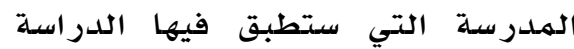

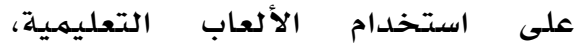
والاتفاق على موعد وخطوات تطبيق الاتيق

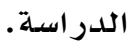

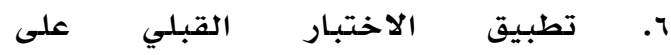

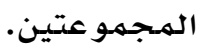

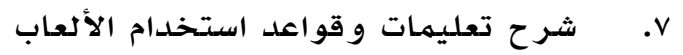

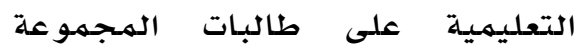
التجر يبيـة.

تنفيذ بر نامج الدراسة خلال الفترة

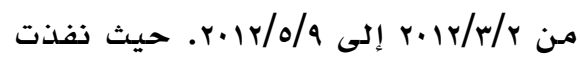

الحلدود الجغرافية: اقتصر تطبيـق الدرّاســة

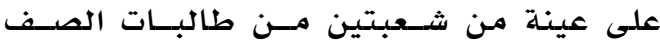

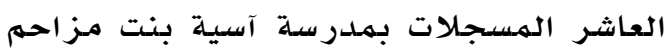

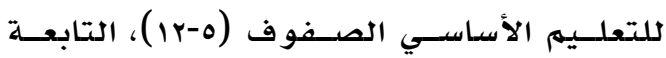

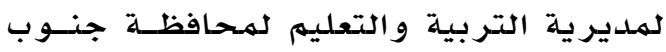
الباطنة.

الحدود الزمانيـة: اقتصــر تطبيـق الدّراســة

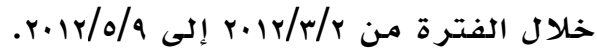

مصطلحات الدر اسة

التدريس باستخدام الألعاب التعليمية: هي طريقة تدريس يكون التعلهم فيها من خلال

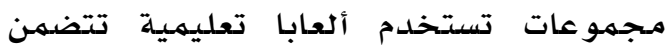
معلومات و أنشطة تتعلق بالثقافة المهنية ويبذل المتعلمون جهدا لتعلهمها كما تتطلب تفاعلهم و وتعاونهم تحقيق أهداف معينة ضمن قواعد وقوانين محددة مسبقا، ويثار

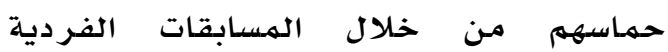
والجماعية، ويقتصر دور الهعلم فيها على له

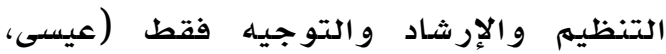

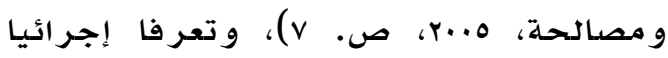
بطريقة التدريس التي تعتمدد على استخدام

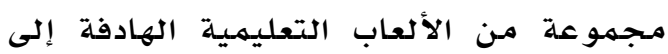

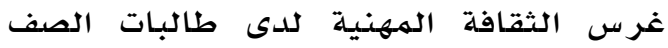
العاشر، و التي قامت أخصائية توجيه الهمهني

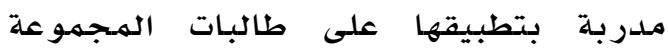
التجريبية في حصص التوجيه الههني لهدة شهر ين. الطريقة التقليدية في التدريس: هي طريقة التدريس الشائعة في مدارسنا، والتي يهيمن فيها المعلهم على سير خطوات الدرس، ودور

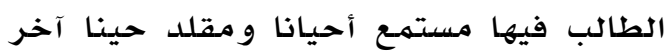
وتقوم على استخدام الأنشطة الموجودة في

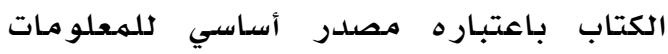

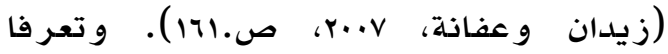

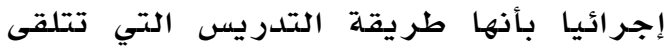

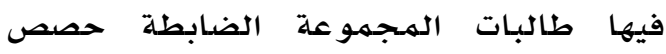

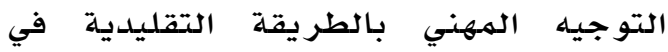

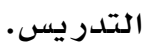


(0...) في اكتساب طالبات الصف العاشر

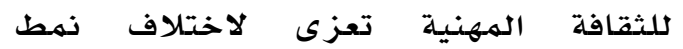

التدريس (نمط التدريس التقليدي، و نمط التهميل

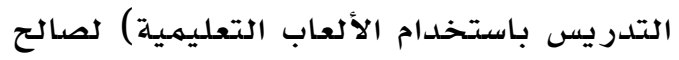

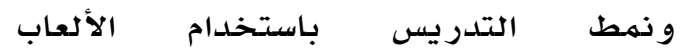

$$
\text { التعليمية" التهمية }
$$

لاختبار صحة فرضيات الدّراسـة تم استخراج المتوسطات الحسابية والانحر افات الهعيارية

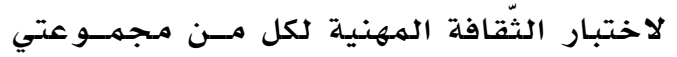
الدرّراسـة، كما يتضح من جدو ل م.

ثم تم استخدام اختبـار تحليل التغاير لمعرفة دلالة الفروق بين (ANCOVA) متوسطي المجمهوعتين في اختبـار الثقافة

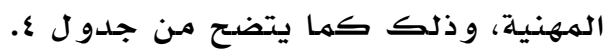
يلاحسظ مسـن جــدول ع وجــود فـروق دالــة

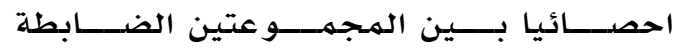
و التجر يبيـة علـى أداء الطالبـات فـي اختبــار

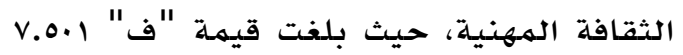

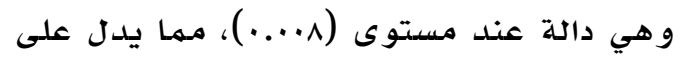

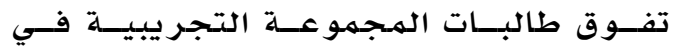

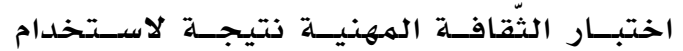

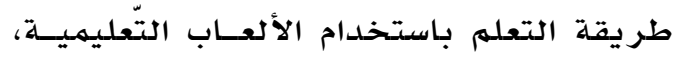

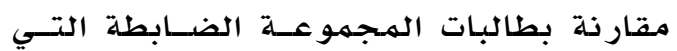
تعلمت بالطّريقة التّقليدية.
الأخصائية المدربة على التدريس

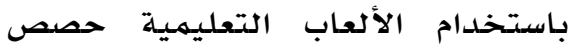

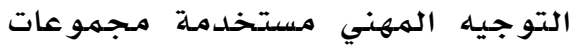

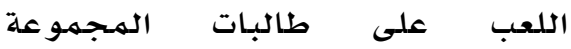
التجريبية، بينما استمرت الأخصائية الأخرى في تقديم حصص التوجيه

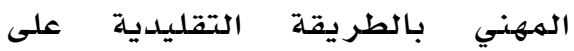
طالبات المهجموعة الضابطة.

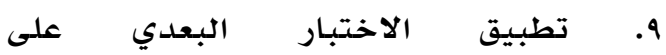
المجمهو عتين.

•. إجراء المعالجات الإحصائية اللازمة لاستخلاص نتائج الدر اسـة.

\section{الأساليب الاحصائية}

لاختبار صحسة فرضيات الدراسـة تم استخر اج المتوسطات الحسابية والانحر افات المعيارية

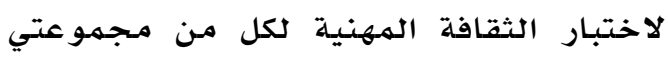

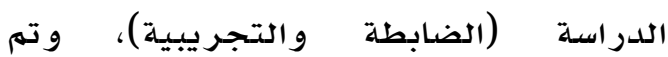
استخدام اختبار " "ت" للتحقق من من تلهافؤ

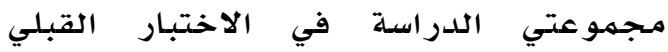
للثقافة المهنية، بينها استخدم اختبار تحليل

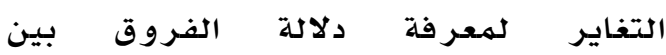
الهتوسطين في الاختبار البعدي للثقافة الههنية الهوتئ.

\section{نتائج اللدراسة}

نتائج فر ضيات الدراسـة و نصد: "توجد فروق

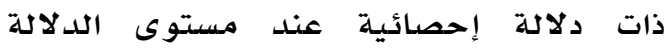

جدول ra

المتوسط الحسابي والانحراف المعياري لدرجات طالبات المجموعتين في الاختبار البعدي للثقافة المهنية

\begin{tabular}{|c|c|c|c|c|}
\hline الانحراف المعياري & المتوسط الحسابي & الدرجة الكلية للاختبار & 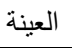 & طريقة التدريس \\
\hline E.T. & ห9.7) & 0 . & זr & المجموعة التجريبية نمط الألعاب التعليمية المهنية) \\
\hline r.vi & ro.vr & 0 . & זr & المجموعة الضابطة نمط التدريس التقليدي) \\
\hline
\end{tabular}

\section{جدول \&}

نتائج تحليل التغاير للمتوسط الحسابي للرجات الطلبة في اختبار لارجات طالبات المجموعتين في الاختبار البعدي للثقافة المهنية

\begin{tabular}{|c|c|c|c|c|c|c|}
\hline مستوى الدلالة & قيمة "ف" & متوسط المربعات & درجات الحرية & مجموع المربعات & مصدر التباين & الدرجة \\
\hline$\ldots 11$ & $0.9 Y_{1}$ & 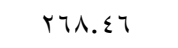 & 1 & หษ人.รT & الاختبار القبلي & الدرجة الكلية \\
\hline \multirow[t]{3}{*}{$\cdots \cdots$} & $v .0 .1$ & $r \varepsilon \cdot, l$ & 1 & $r \leq . .1$ & الطريقة & \\
\hline & & $\leq 0 . r \leq$ & זי & $r 9.1 .11$ & الخطأ & \\
\hline & & & 70 & $\varepsilon 11 \vee 9 .$. & الكلي & \\
\hline
\end{tabular}


التوصيات

من خــلال نتـائج الدّر اســة الحساليسة، توصـي الباحثة بالآتي:

أولا: توصـيات كـوزارة التربيــة والتعلـيم والمركز الوطني للتوجيه المهني:

ا. إنتاج بر مجيات تعليميسة فـي مجــال

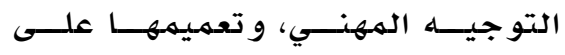

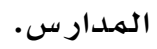

r. تورورة استخدام الألعاب التربوية في

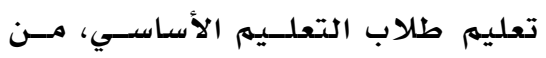
خلال إضافة قاعة لكل مدرسة بفريق

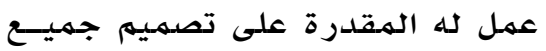
الألعاب في الهواد المختلفة، لتساعد

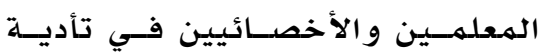
الألعاب بشكل بسيط و هادف.

r. مـر اعـاة و اضـعي المنــاهـج لمـرحلــة

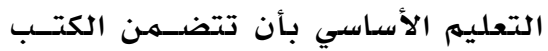

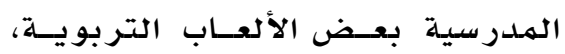

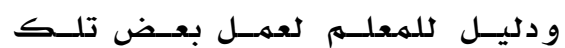

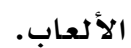

ع. إنشاء قنــاة تعليميـة تحست إثــر اف

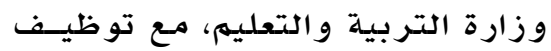

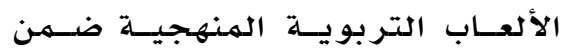

بر امجها.

ثانيا: توصيات لأخصائيي التوجيه المهني

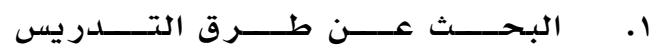

و الاستر اتيجيات الحديثـة و تطبيقهـا

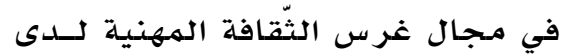

الطلبـة.

تصميهم بر مـجيات، و ألعـاب، و أنثـطة

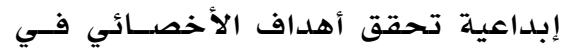
نشر الثّقافة الههنية بين الطلبهة.

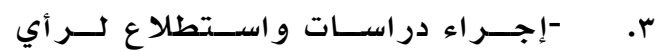
الطلبة في الأساليب والاسـتراتيجيات دراس والهات المفضلة لديهم في التعلهم.

\section{مناقشة النتائج}

بينت نتائج الدراسـة تفوق طالبـات المهجموعة

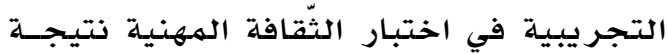

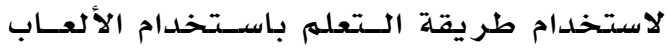

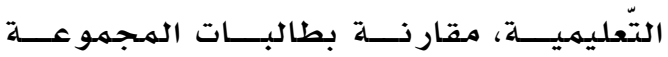

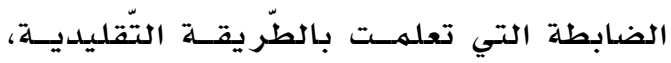
و تعزو الباحثة هذه النتيجة إلى أهميـة دور

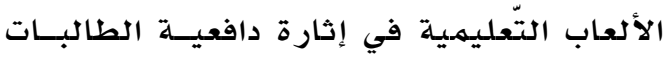

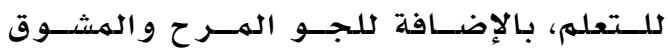

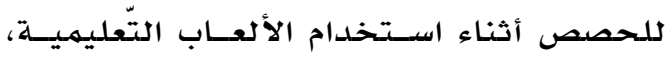

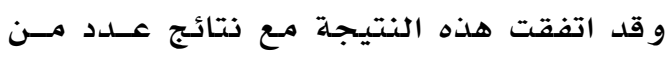

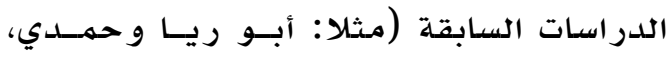

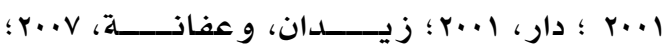

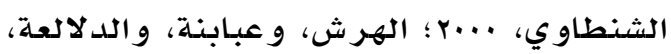

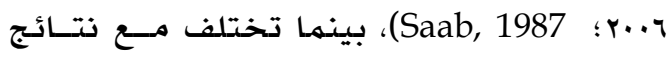
دراسات أخرى لهم تجد فروقا داتسة إحصـائيا

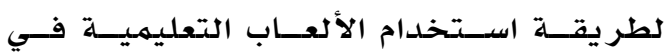
تحصيل الطلبـة (عبيدات، ه... م). كما تفسر الباحثة هذه النتيـجسة فـي ضــوء

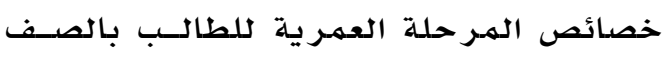

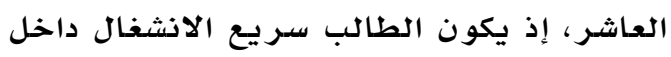

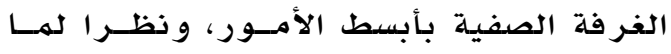

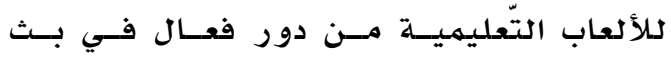

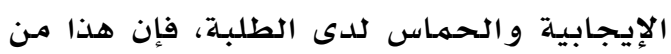

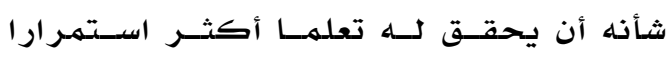
و فائدة، بجانب ما قد يهيئه مـن فر ص لصسقل

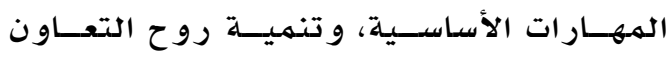

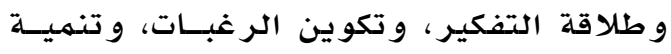

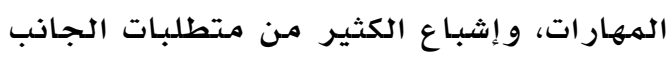

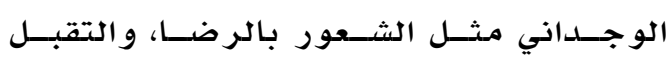
و التوافق مـع الحيـاة الملدرسـية ومتـطلبـاتهـا.

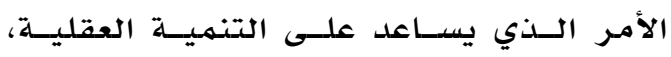

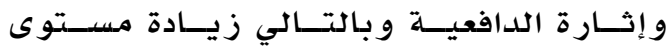

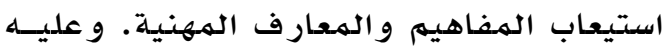

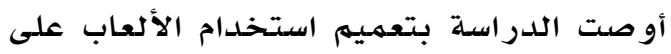

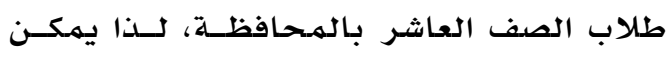
قبول فر ضية الدر اسـة. 
السمـع في مـرحلة ما قبل المـدرسة.

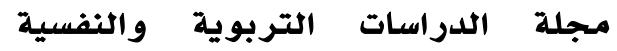

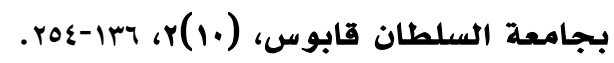
الجامودي، سعيد ساله (r.v. (r). إسهام مديري مدارس سلطنة عمان في التوجيه المهني

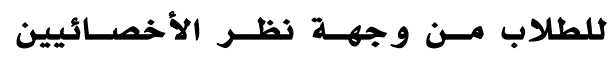

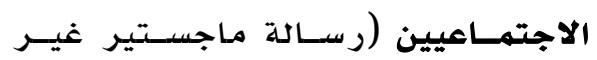
منشورة)، جامعة السلطان قابوس. إسل ماجئ

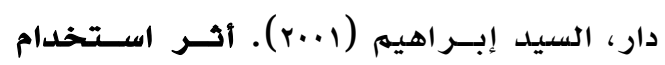

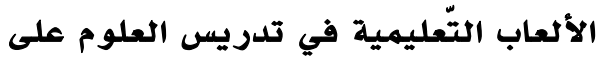

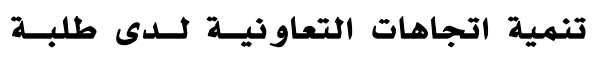

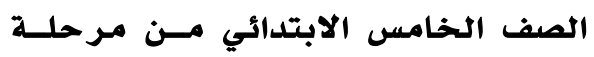
التعليم الأساسي (رسالة ماجستير غير

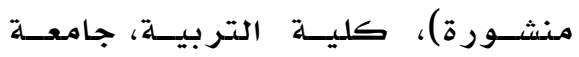

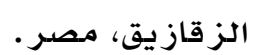
زيدان، عفيف، و عفانة، انتصـار (V.... (r). أثـر

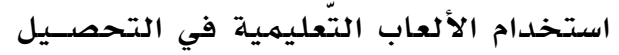

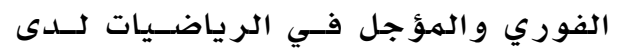

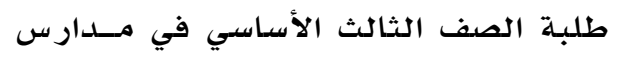
ضواحي القدس، مـجلــة جامعــة النجــاح

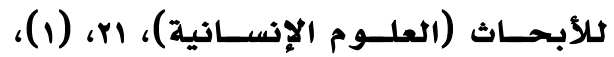
$.11 \cdot-17$.

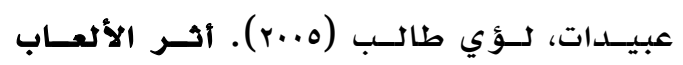
التربوية المحوسبة في تحصـيل بعسض المض المبل المفاهيم الرياضية لطلبة الصف الثالث الأساسي في مديرية إربد الأولى (رسالة المفافية المفية المالث

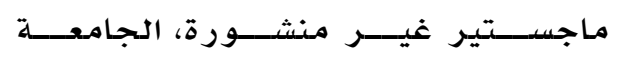
الهاشمية)، الزرقاء، الأردن.

عيسى، حازم، و مصالحة، عبد الهـادي (م.r).

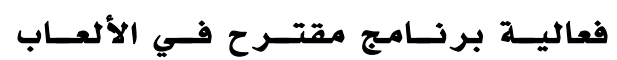

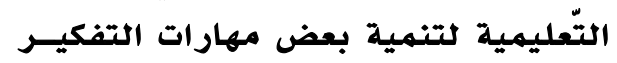

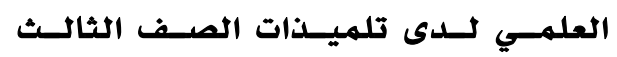

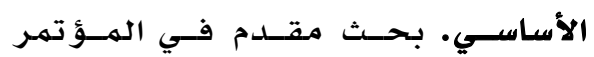

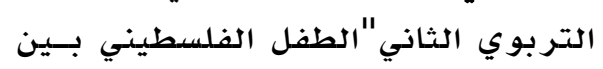

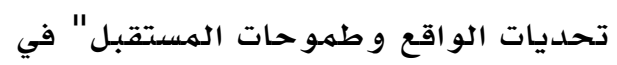

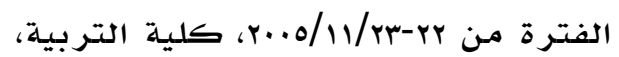
الجـامعة الإسـلامية.
المقتر حات

تقتـــر ح البـاحثـــة إجـــر اء در اســـات أخـــرى

باستخدام استراتيجيات التدريس الحديثة في إجياء

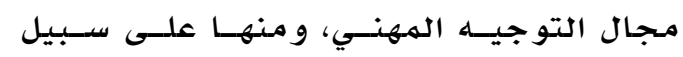

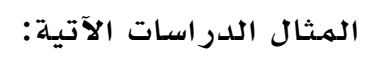

ا. درراســة عـن أثـر اسـتخدام الألعـاب

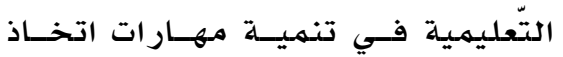

القرار الهمهني.

Y. دراســة عـن أثـر اسـتعمهال الألعــاب

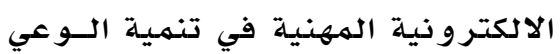

الههني لدى الطلبـة.

المراجع

References

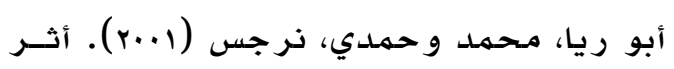

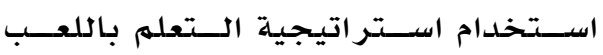
المنفذة من خلال الحاسوب في الكتساب طلبة الصف السـادس الأساسـي لهمهـارات

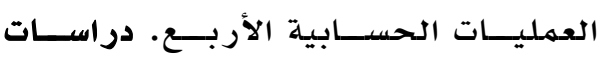

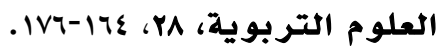

أبو مايلة، حسن السـيد (1991). دور اللعسب

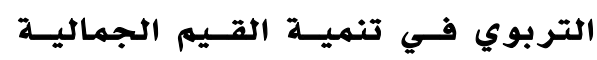

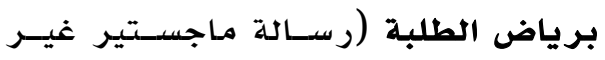

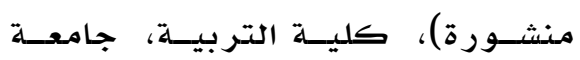
المنصورة، مصر • ملهورة

آل جميـل، يســرية (·r.r). أدـر اسـتخدام

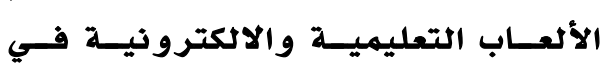

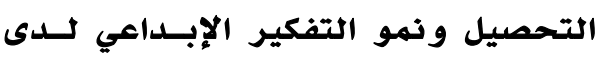
طالبات الصــف السـادس الابتـدائي فـي مقرر اللغة الانجليزية. اسـترجعت مسن

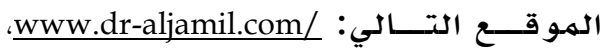

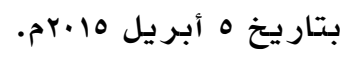

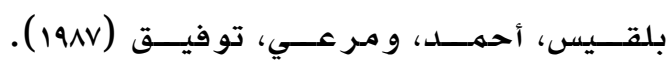
الميسر في سيكولوجية اللعـب. عمـان: دار الفرقان للنشر والتوزيع.

تركستاني، مريم حافظ عمر (17. (ا). أثر

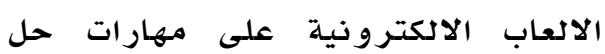
المشكلات لدى عينة مـن الأطفال ضعاف 
Aikaterini, K., Apostolos, M., \& Thrasyvoulos, T. (2014). Implementing a Game for Supporting Learning in Mathematics. The Electronic Journal of e-Learning (12)3, 230-242.

Engels, H., \& Geralien A (1994). Computer-based Role- Playing For interpersonal Skills. Training, simulation \& gaming, 28 (2), 164-180.

Kablan, Z. (2010). The Effect of Using Exercise-based Computer Games during the Process of Learning on Academic Achievement among Education Majors. Educational Sciences: Theory E Practice, 10 (1), 351-364.

Saab, J. F. (1987). The Effects of Creative Drama Methods on Mathematics Achievement, Attitudes and Creativity (Unpublished PhD Dissertation), West Virginia University, Morgantown.

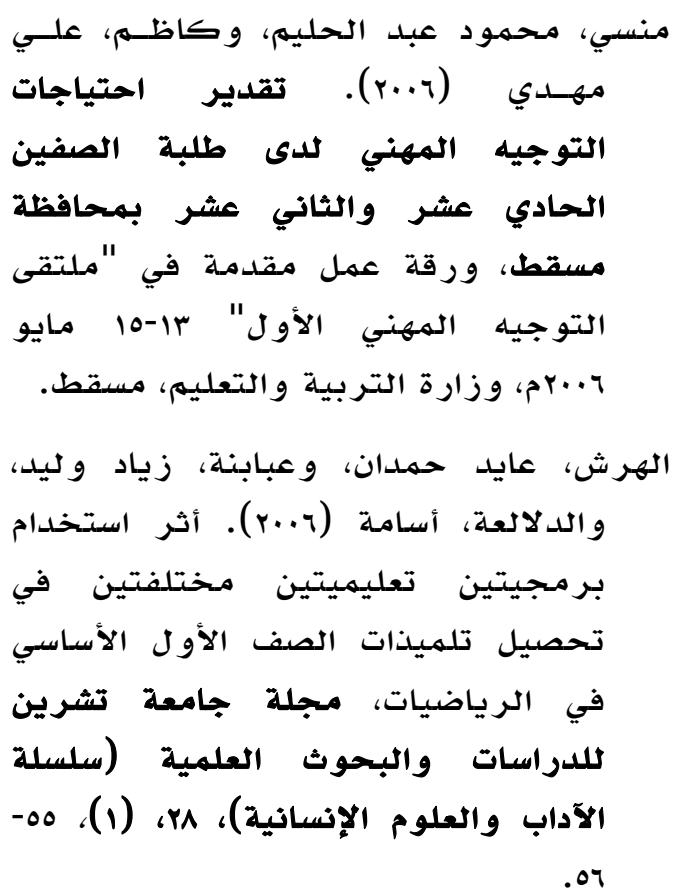

